\title{
Hypothesis of Opposite Interplay Between the Canonical WNT/beta-catenin Pathway and PPAR Gamma in Primary Central Nervous System Lymphomas
}

\author{
Alexandre Vallée ${ }^{1 *}$, Yves Lecarpentier ${ }^{2}$ and Jean- \\ Noël Vallée ${ }^{3,4}$ \\ ${ }^{1}$ Délégation à la Recherche Clinique (DRCl), Hôpital \\ Foch, Suresnes, France. \\ ${ }^{2}$ Centre de Recherche Clinique, Grand Hôpital de \\ l'Est Francilien (GHEF), Meaux, France. \\ ${ }^{3} \mathrm{CHU}$ Amiens Picardie, University of Picardie Jules \\ Verne (UPJV), Amiens France. \\ ${ }^{4}$ Laboratory of Mathematics and Applications (LMA), \\ UMR CNRS 7348, University of Poitiers, Poitiers, \\ France.
}

*alexandre.g.vallee@gmail.com

DOI: https://dx.doi.org/10.21775/cimb.031.001

\begin{abstract}
Primary central nervous system lymphomas (PCNSLs) are angiocentric neoplasia which present dense monoclonal lymphocyte proliferation, and occur in brain parenchyma in $90 \%$ of the cases. Activated B-cell like Diffuse Large B-cell Lymphoma (ABC-DLBCL) subtype represents more than $90 \%$ of PCNSLs and is the most aggressive subtype with a cure rate of only $40 \%$. One of the characteristics of $A B C-D L B C L$ subtype is neuroinflammation through the activation of NF-kappaB pathway. c-Myc alterations and protein expression have been shown in aggressive DLBCL. C-Myc is considered as a key prognostic and predictive biomarker for survival in DLBCL, its expression is associated with worst survival rates. Although mRNA of c-Myc is increased by low levels gains of c-Myc, several studies have shown that c-Myc protein expression is overexpressed without c-Myc abnormalities. These high levels of c-Myc protein in DLBCL without genetic abnormalities suggest that c-Myc protein expression may be also increased by other
\end{abstract}

mechanisms or signaling pathways which regulate its expression. In PCNSLs, the canonical WNT/betacatenin pathway is upregulated while PPAR gamma is downregulated. The opposite interplay between WNT/beta-catenin pathway and PPAR gamma is reviewed here. Activation of WNT/beta-catenin pathway leads to the transcription of genes involved in cell proliferation, mitochondrial metabolism, protein synthesis, and tumor growth, such as c-Myc. PPAR gamma agonists induce the inhibition of several signaling pathways such as NF-kappaB, STAT, PI3K/Akt and WNT/beta-catenin pathway. Activation of PPAR gamma agonists may have a major negative key role in the regulation of PCNSLs progression.

\section{Abbreviations}

APC: Adenomatous polyposis coli

CNS: Central nervous system

DLBCL: diffuse large $B$ cell lymphoma

DSH: Disheveled

EGFR: epidermal growth factor receptor

FZD: Frizzled

GSK-3beta: Glycogen synthase kinase-3beta

JAK: Janus Kinase

LRP 5/6: Low-density lipoprotein receptor-related protein 5/6 PI3K-Akt: Phosphatidylinositol 3-kinase-protein kinase B PCNSL: Primary central nervous system lymphoma

PPAR gamma: Peroxisome proliferator-activated receptor gamma

STAT3: signal transducer and activator of transcription 3 TCF/LEF: T-cell factor/lymphoid enhancer factor

\section{Introduction}

Primary central nervous system lymphomas (PCNSLs) are angiocentric neoplasia which present dense monoclonal lymphocyte proliferation, and occur in brain parenchyma in $90 \%$ of the cases. PCNSLs are infiltrative and extend beyond the primary lesion. PCNSLs account for up to $1 \%$ of 
Non-Hodgkin lymphomas (NHL) and 3\% of primary brain tumors (Villano, Koshy, Shaikh, Dolecek, and McCarthy, 2011). Angiotropism characterizes both primary and metastatic central nervous system (CNS) lymphomas unlike malignant gliomas which are vascular tumors (Aho, Ekfors, Haltia, and Kalimo, 1993). CNS vasculature contributes to the pathogenesis of PCNSL because large B celllymphoma accumulates densely around brain tumor vessels. The prognosis of PCNLs is worse than other localized extranodal lymphomas (Abrey, DeAngelis, and Yahalom, 1998; Fine and Mayer, 1993). Around $90 \%$ of PCNSL are diffuse large $B$ cell lymphomas (DLBCL). Two molecular subtypes form DLBCL; activated B-cell like $(A B C)$ and germinal center B-cell like (GCB) (Alizadeh et al., 2000; Georg Lenz and Staudt, 2010).

ABC-DLBCL subtype represents more than $90 \%$ of PCNSLs (Batchelor, 2016) and is the most aggressive subtype with a cure rate of only $40 \%$ (G. Lenz et al., 2008). One of the characteristics of ABC-DLBCL subtype is the activation of NF-kappaB pathway whereas GCB-DLBCL presents low levels of this signaling (Pasqualucci and Zhang, 2016). NF-kappaB is a downstream signaling of both $B$ cell receptor (BCR) and $C D 40$ receptors and $A B C$ DLBCL cells show a "chronic and active" form of BCR signaling (R. Eric Davis et al., 2010). MYD88 mediates the activity of NF-kappaB as well as type I interferon responses (S.-C. Lin, Lo, and Wu, 2010). MYD88 mutations are observed in around $30 \%$ to $40 \%$ of ABC-DLBCL. MYD88 mutations stimulates STAT3 signaling which is also a phenotypic trait of ABC-DLBCL subtype (Ngo et al., 2011).

c-Myc alterations and protein expression have been shown in aggressive DLBCL (Karube and Campo, 2015). These alterations are frequently associated with oncogenic abnormalities, as B-cell lymphoma 2 $(\mathrm{Bcl}-2)$ and B-cell lymphoma 6 (Bcl-6) genes translocation and overexpression (Karube and Campo, 2015). c-Myc rearrangements appear similarly expressed in both GCB and ABC-DLBCL (Johnson et al., 2012). Although mRNA of c-Myc is increased by low levels gains of c-Myc, several studies have shown that c-Myc protein expression is overexpressed without c-Myc abnormalities (Horn et al., 2013; Johnson et al., 2012; Stasik et al., 2010; Valera et al., 2013). These high levels of c-Myc protein in DLBCL without genetic abnormalities suggest that c-Myc protein expression may be also increased by other mechanisms or signaling pathways which regulate its expression (Meyer and Penn, 2008).
In numerous tissues, canonical WNT/beta-catenin pathway activation induces inactivation of peroxisome proliferator-activated receptor gamma (PPAR gamma), while PPAR gamma activation induces inhibition of canonical WNT/beta-catenin pathway (Lecarpentier, Claes, Duthoit, and Hébert, 2014). WNT/beta-catenin pathway, a determining factor in the evolution of numerous cancers (Gruetter, 2003; Thompson, 2014; Warburg, 1956), is increased in DLBCL (Walker et al., 2015; Yan Zhang et al., 2014). Inflammation and WNT/betacatenin pathway act in a positive interplay (Ma and Hottiger, 2016). c-Myc is a WNT target gene (Angers and Moon, 2009). PPAR gamma is low expressed in CNS and observed in several cell types such as neurons, astrocytes, oligodendrocytes and microglia (Lambiv et al., 2011; Sarin and Bernath, 2008; J. Wu et al., 2012; Z. Yang et al., 2010). In many pathophysiological states, PPAR gamma activation induces repression of the WNT/beta-catenin pathway (J. Liu, Wang, Zuo, and Farmer, 2006; Moldes et al., 2003; Sharma, Pradeep, Wong, Rana, and Rana, 2004). PPAR gamma agonists show benefic roles in DLBCL (X. $\mathrm{Li}, \mathrm{Du}, \mathrm{Xu}$, Lin, and Ling, 2013). Anti-inflammatory properties of PPAR gamma agonists may partly explain their beneficial therapeutic effects. PPAR gamma agonists can decrease the activation of WNT/beta-catenin pathway and represent a promising therapeutic target for PCNSL patients.

We focus this review on the hypothesis of an opposite interplay between the canonical WNT/betacatenin pathway and PPAR gamma in regulating the molecular mechanisms underlying the PCNSLs.

\section{Canonical WNT/beta-catenin pathway}

Wingless and integration site (named WNT) pathway is a cascade of several signaling which is involved in development, metabolism, cellular growth, and maintain of stem cells (van Amerongen and Nusse, 2009). WNT pathway is composed by secreted lipid-modified glycoproteins (Al-Harthi, 2012). Dysregulation of the WNT pathway is involved in several pathways (Lecarpentier et al., 2014). Aberrant WNT/beta-catenin pathway is observed in cancer development (Sumithra, Saxena, and Das, 2016). WNT extracellular ligands bind Frizzled (FZD) receptors and low density lipoprotein receptor-related protein 5 and 6 (LRP $5 / 6$ ) and disheveled (DSH), which induce betacatenin accumulation and then beta-catenin nuclear translocation for binding T-cell factor/lymphoid enhancer factor (TCF/LEF). (Logan and Nusse, 
2004). Nuclear beta-catenin associated with TCF/ LEF activates several target genes expression such as c-Myc, cyclin D1 (Angers and Moon, 2009). Downregulation of the WNT pathway is characterized by the absence of binding between WNT extracellular ligands and the complex FZD/ LRP 5/6. Thus, the beta-catenin destruction complex composed by adenomatous polyposis coli (APC), AXIN and glycogen synthase kinase-3 (GSK-3beta) is activated and mediates proteasomal degradation of beta-catenin (Clevers and Nusse, 2012). GSK-3beta inhibits cytosolic beta-catenin accumulation and nuclear translocation (Aberle, Bauer, Stappert, Kispert, and Kemler, 1997; Clevers and Nusse, 2012).

In non-Hodgkin lymphoma patients, MMP-2 and MMP-9 have a major role in ECM degradation (Kossakowska et al., 1999). Beta-catenin promotes MMP-2 and MMP-9 expressions by regulating COX-2 activity to increase invasion and metastasis of tumors (H. Kim et al., 2013; Z.-H. Peng et al., 2011).

\section{WNT pathway in DLBCLs (Figure 1)}

The Forkhead box protein P1 (FOXP1) is a transcription factor which participates to tissue homeostasis, development and regeneration (Katoh, Igarashi, Fukuda, Nakagama, and Katoh, 2013; Koon, Ippolito, Banham, and Tucker, 2007). Proper B-cell development needs FOXP1 expression, FOXP1 deficient lymphoid stem cells fail to differentiate and overexpression of FOXP1 decreases B-cell maturation ( $\mathrm{Hu}$ et al., 2006; Sagardoy et al., 2013). FOXP1 has anti-apoptotic activity and is considered as an oncogene in B-cell lymphomas (van Keimpema et al., 2014). FOXP1 is an enhancer of WNT/beta-catenin pathway transduction (Walker et al., 2015). Several studies have shown that WNT/beta-catenin pathway is increased in DLBCLs (Ge, Lv, Feng, Liu, and Wang, 2012; Koch et al., 2014; Qiang, Endo, Rubin, and Rudikoff, 2003; Reya et al., 2000; Staal et al., 2001).

\section{Interactions between WNT pathway and PI3KJAkt pathway}

Phosphatidylinositol 3-kinase/serine/threonine kinase (protein kinase $\mathrm{B}$ )/mammalian target of rapamycin (PI3K/Akt/mTOR) pathway is present in cell growth, proliferation, protein synthesis and energetic metabolism (Brazil, Yang, and Hemmings, 2004; Ciuffreda, Di Sanza, Incani, and Milella, 2010; Heras-Sandoval, Pérez-Rojas, Hernández-Damián, and Pedraza-Chaverri, 2014; Yu and Cui, 2016).
WNT/B-catenin pathway is considered as an upstream activator of PI3K/Akt/mTOR pathway (J. Chen, Alberts, and Li, 2014) through the inhibition of GSK-3 $\beta$ (Huang, Nguyen-McCarty, Hexner, DanetDesnoyers, and Klein, 2012). In addition, decrease of beta-catenin signaling downregulates the expression of PI3K/Akt/mTOR pathway (K. S. Park et al., 2004; Yue et al., 2010). Moreover, in adipocyte differentiation, activated PI3K/Akt pathway can induce inhibition of GSK-3 $\beta$ (Ross, Erickson, Hemati, and MacDougald, 1999; Tang et al., 2005). PTEN is a PI3K inhibitor, and PTEN deletions are often observed in DLBCLs (Knittel, Liedgens, Korovkina, Pallasch, and Reinhardt, 2016).

\section{2. c-Myc}

c-Myc expression is observed in $30 \%$ to $50 \%$ DLBCL (Chisholm et al., 2015; Karube and Campo, 2015). c-Myc expression is concomitant to Bcl-2 rearrangement in $60 \%$ to $80 \%$ of DLBCL (Pedersen et al., 2014; Pillai, Sathanoori, Van Oss, and Swerdlow, 2013; Valera et al., 2013) and to Bcl-6 rearrangements but in a lower frequency (Pillai et al., 2013). c-Myc expression is more frequent in GCB-DLBCLs but also found in ABC-DLBCL (David et al., 2017; Valera et al., 2013). c-Myc is involved in human cancers and its expression participates to the development of B-cell lymphomas (Sheiness, Fanshier, and Bishop, 1978). c-Myc controls several functions, such as cell cycle, cell growth, cellular metabolism, protein synthesis, adhesion and mitochondrial function (Dang et al., 2006). c-Myc is considered as a key prognostic and predictive biomarker for survival in DLBCL, its expression is associated with worst survival rates (Johnson et al., 2012; Kluk et al., 2012; Perry et al., 2014; Valera et al., 2013; Zhou et al., 2014). c-Myc rearrangement is correlated with poor progression-free survival and overall survival in R-CHOP chemotherapy patients(Delmore et al., 2011; Kluk et al., 2012). $\mathrm{Bcl}-2, \mathrm{Bcl}-6$ and BLIMP1 rearrangements are largely associated with c-Myc expression (Boi et al., 2015; Hnisz et al., 2013; Whyte et al., 2013). In normal conditions, c-Myc is not expressed because Bcl-6 and BLIMP1 physiologically repress its expression (Karube and Campo, 2015; Y. Lin, Wong, and Calame, 1997; A. L. Shaffer et al., 2000). BCL6 expression suppresses c-Myc transcription by directly binding to its promoter (Basso et al., 2010; Ci et al., 2009, p. 6; Nahar et al., 2011). In DLBCLs, BLIMP1 disruption increases c-Myc expression (Wierstra and Alves, 2008). Activation of B-cell receptor (BCR), CD40 (cluster designation 40) and interleukin-2 (IL-2) receptors suppresses Bcl-6 
activity and then prevents the inhibition of c-Myc by Bcl-6 to allowing cell division (De Silva and Klein, 2015; Oestreich, Mohn, and Weinmann, 2012).
3. NF-kappaB pathway in ABC-DLBCL

NF-kappaB signaling is a main effector of inflammation (Ben-Neriah and Karin, 2011; Karin, 2009; Pasparakis, 2009), its deregulation is implicated in numerous inflammatory processes (Ben-Neriah and Karin, 2011; Pasparakis, 2009; Tak

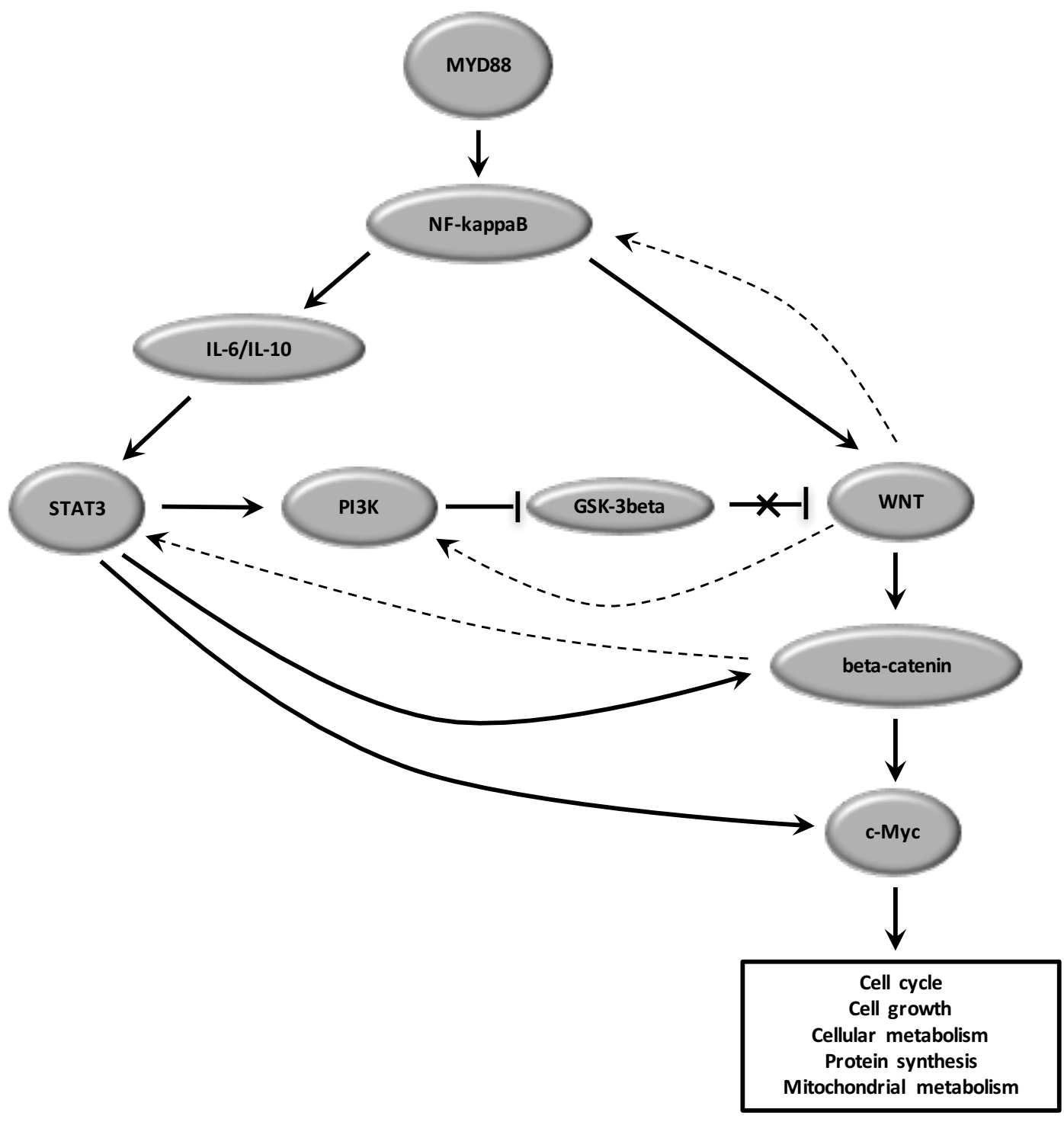

Figure 1. Oncogenic pathways involved in PCNSL. MYD88 mutations stimulate NF-kappaB activity and the neuroinflammation leading to activate IL-6 and/or IL-10. Activation of these interleukin promotes STAT3 signaling to activate PI3K/Akt pathway. PI3K inhibits GSK-3beta, the major WNT inhibitor. In PCNSL, WNT is directly activated by NF-kappaB and PI3K through the inhibition of GSK-3beta. In PCNSL, WNT ligands bind FZD receptors, LRP 5/6 and DSH, which induce beta-catenin accumulation and then beta-catenin nuclear translocation. STAT3 signaling also directly stimulates beta-catenin accumulation and c-Myc activation. In a positive feedback, WNT/beta-catenin pathway stimulates NF-kappaB, PI3K and STAT3. Nuclear beta-catenin activates cMyc leading to stimulate cell cycle, cell growth, cellular metabolism, protein synthesis and mitochondrial metabolism. 
and Firestein, 2001). NF-kappaB is a family of transcription factors which controls several genes implicated in B-cell activation, proliferation and antiapoptotic activity (Qiutang Li and Verma, 2002). NFkappaB activity is frequently observed in DLBCL (A. L. Shaffer, Rosenwald, and Staudt, 2002). ABCDLBCLs show high expression of NF-kappaB (Georg Lenz and Staudt, 2010) whereas GCBDLBCL have virtually absent levels of NF-kappaB (R. E. Davis, Brown, Siebenlist, and Staudt, 2001). NF-kappaB is considered as a hallmark of ABCDLBCL (Lam et al., 2008; Rui et al., 2016). Overexpression of NF-kappaB in ABC-DLBCLs is due to CD40 activation (Pham et al., 2002), or TNFAIP3 (A20) and MYD88 mutations (Roschewski, Staudt, and Wilson, 2014). High prevalence of MYD88 mutations is correlated with activation of BCR and NF-kappaB pathway in $90 \%$ of PCNSL cases (Batchelor, 2016; Braggio et al., 2015; Chapuy et al., 2016). Several genomically hardwired aberrations in cellular signaling in $A B C$ DLBCL activate NF-kappaB pathway (Arthur L. Shaffer, Young, and Staudt, 2012). Nuclear translocation of NF-kappaB transactivates numerous target genes, including $\mathrm{Bcl}-2$ family members (Tracey et al., 2005; Vallabhapurapu and Karin, 2009). MYD88 mutations engage NF-kappaB pathway to induce production of IL-6 and IL-10 in ABC-DLBCL (R. Eric Davis et al., 2010).

\section{Interactions between WNT pathway and NF-kappaB pathway}

Several studies have shown an interplay between canonical WNT/beta-catenin pathway and NFkappaB signaling ( $\mathrm{Ma}$ and Hottiger, 2016). Inflammation and immune response are modulated by this interaction between WNT/beta-catenin pathway and NF-kappaB (Ma and Hottiger, 2016; Nejak-Bowen, Kikuchi, and Monga, 2013; Oguma et al., 2008; Yuhang Zhang et al., 2009). Overexpression of WNT/beta-catenin pathway increases the NF-kappaB-mediated anti-apoptotic action (Noubissi et al., 2006; Spiegelman et al., 2000), and activates inflammatory processes through the stimulation of beta-catenin targets genes (Anson et al., 2012; Kuphal, Poser, Jobin, Hellerbrand, and Bosserhoff, 2004). WNT/betacatenin pathway inhibits prolyl-hydroxylase and then activates NF-kappaB signaling (Cummins et al., 2006; Scholz et al., 2013). GSK3-beta upregulation also decreases NF-kappaB signaling (Buss et al., 2004; Saegusa, Hashimura, Kuwata, Hamano, and Okayasu, 2007). Beta-catenin accumulation activates NF-kappaB pathway in ABC-DLBCL cell lines (Bognar et al., 2016).
Moreover, the NF-kappaB signaling activates canonical WNT/beta-catenin pathway (Lamberti et al., 2001). NF-kappaB activation stimulates the expression of the TCF/LEF complex and provides an indirect positive control of WNT/beta-catenin pathway (Yun, Choi, Nam, Park, and Im, 2007). Stimulation of IKKB kinase (IKK) alpha, an activator of NF-kappaB, leads to cytosolic accumulation of $\beta$ catenin and then activates WNT/beta-catenin pathway targets genes (Albanese et al., 2003; Lamberti et al., 2001).

\section{Interactions between c-Myc and NF-kappaB pathway}

The proliferative index of B-cell lymphomas is largely due to the activation of NF-kappaB pathway but also due to the dysregulation of c-Myc activity (Ott, Rosenwald, and Campo, 2013). c-Myc participates to the proliferation of NF-kappaB activated B cells (David et al., 2017). The interplay between NF-kappaB and STAT pathway upregulates c-Myc expression in ABC-BLBCLs (Ding et al., 2008).

\section{STAT pathway in ABC-DLBCLs}

IL-6, epidermal growth factor (EGFR), or interferons stimulate Janus kinase (JAK) to activate signal transducer and activator of transcription 3 (STAT3) (Akira et al., 1994; Hirano, Ishihara, and Hibi, 2000; Levy and Lee, 2002). JAKs phosphorylate STAT3 at tyrosine -705 (Tyr-705) to dimerize and translocate it to the nucleus where it activates several target gens (O'Shea, 1997). Phosphorylation at Serine-727 (Ser-727) activates STAT3 in response to cytokine stimulation (Decker and Kovarik, 2000; Schuringa, Schepers, Vellenga, and Kruijer, 2001; Wen, Zhong, and Darnell, 1995). STAT pathway is aberrantly activated in ABC-DLBCL (Ding et al., 2008) and regulates genes expression to promote survival of malignant cells (Hardee et al., 2013; Scuto et al., 2011). STAT pathway induces several genes expression, including c-Myc (Rui et al., 2010, 2016). MYD88 activates NF-kappaB pathway which induces IL-6 and IL-10 expression to stimulate JAK/ STAT pathway (E. Chen, Staudt, and Green, 2012; Stark and Darnell, 2012). STAT3 forms a complex with several NF-kappaB transcription factors to regulate several genes such as NFKBIA, NFKBIZ, CXCR5, CD44, and PIM2 (Hardee et al., 2013; J. Yang et al., 2007). IL-4, IL-10 and STAT pathway overexpression are correlated with aberrant activation of MYD88 pathway (Paydas, 2017). 
Interactions between STAT3 signaling and WNT/ beta-catenin pathway

Activation of WNT/beta-catenin pathway is related to PI3K/Akt pathway through its inhibition of GSK-3beta (Voskas, Ling, and Woodgett, 2010), and directly by STAT3 (Michaud-Levesque, Bousquet-Gagnon, and Béliveau, 2012) which is also connected with PI3K/Akt pathway (Vogt and Hart, 2011; Yokogami, Wakisaka, Avruch, and Reeves, 2000). In hepatocellular carcinoma, STAT3 signaling regulates beta-catenin and GSK-3beta protein expression (Wang et al., 2011). Betacatenin/TCF complex directly binds to the STAT3 gene promoter to activate it (Yan et al., 2008). In breast cancer, STAT3 signaling stimulates the expression and transcriptional activity of betacatenin (Armanious, Gelebart, Mackey, Ma, and Lai, 2010). Inhibition of STAT3 blocks glioma cell growth, invasion, migration, differentiation and cell cycle progression (Kang et al., 2010; G.-H. Li, Wei, Lv, Ji, and Wang, 2010; Sherry, Reeves, Wu, and Cochran, 2009).

Interactions between NF-kappaB, STAT3 and PI3K pathways

ABC-DLBCLs show stimulation of cytokines IL-6 and IL-10 which activate STAT3 pathway (Ding et al., 2008; Lam et al., 2008; Scuto et al., 2011). Cytokines production results from high levels of NFkappaB activity (Staudt, 2010). Activation of NFkappaB, STAT3 signaling and PI3K/Akt pathway are concomitant in B cell lymphomas (Dutton, Reynolds, Dawson, Young, and Murray, 2005; Fillmore et al., 2005; Rudelius et al., 2006). These three pathways play a major role in growth control, survival and chemotherapy resistance of B-cell lymphomas (Bhardwaj et al., 2007; Ghosh, Kay, Secreto, and Shanafelt, 2009; Shair et al., 2007). NF-kappaB and STAT3 stimulate c-Myc (Ding et al., 2008; Duyao, Buckler, and Sonenshein, 1990; Kiuchi et al., 1999; Murphy et al., 2008; M. Wu et al., 1996).

\section{PPAR gamma}

Peroxisome proliferator receptor gamma (PPAR gamma) is a ligand activated transcriptional factor which forms a heterodimer with retinoid $X$ receptor (RXR) to activate specific peroxisome response elements (PPRE) (Ahmadian et al., 2013). PPAR gamma expression is involved in several mechanisms such as glucose and lipid metabolism, immune response, and inflammation (Elbrecht et al., 1996; Fajas et al., 1997). PPAR gamma decreases NF-kappaB activity and then represses inflammation (Ricote and Glass, 2007). PPAR gamma is expressed in several cells, such as adipocytes, muscle cells, brain cells, immune cells (Lakatos et al., 2007). 15d-prostaglandin J2 (15d-PGJ2), lysophosphatidic acid, and nitrolinoleic acid are natural activators of PPAR gamma (E. J. Park, Park, Joe, and Jou, 2003), whereas thiazolidinediones (TZDs) and oleanic acid derivatives such as triterpenoids (2-cyano-3,12-dioxoolean-1,9-dien-28oic-acid (CDDO)) are synthetic activators of PPAR gamma. PPAR gamma expression mediates the functions of many signaling such as connective tissue regulation, mesenchymal cell activation, differentiation and cell survival creating a link between metabolism and fibrogenesis (Wei, Bhattacharyya, Tourtellotte, and Varga, 2011).

Numerous inflammatory cytokines, chemokines, or intracellular signaling decrease PPAR gamma expression such as canonical WNT/beta-catenin pathway, TNF-alpha, interleukin (IL)-1, IL-13, Connective Tissue Growth Factor (CTGF), leptin, and lysophosphatidic acid (LPA) (Simon et al., 2005; Tan et al., 2008; Yamasaki et al., 2004). The transcription factor COUP II is a canonical WNT target and represses PPAR gamma expression (Okamura et al., 2009). In adipocytes, adiponectin increases PPAR gamma expression and decreases LPS-induced NF-kappaB expression and IL-6 production (Ajuwon and Spurlock, 2005).

\section{PPAR gamma in ABC-DLBCLs (Figure 2)}

Exposure of DLBCL cells to PPAR gamma ligands results in cell death and induction of apoptosis ( $\mathrm{J}$. Padilla, Kaur, Cao, Smith, and Phipps, 2000; Josué Padilla, Leung, and Phipps, 2002; Ray, Bernstein, and Phipps, 2004). TZDs and 15d-PGJ2 decrease NF-kappaB activation (Ray, Akbiyik, Bernstein, and Phipps, 2005). Telmisartan decreases NF-kappaB activity and MYD88 activation and then blocks neuroinflammation through the stimulation of PPAR gamma (Prathab Balaji, Vijay Chand, Justin, and Ramanathan, 2015). Rosiglitazone increases levels of $\mathrm{Bcl}-2$ and decreases levels of $\mathrm{Bcl}-2$ associated $\mathrm{X}$ protein (Bax) in spinal cord tissue (X. Li et al., 2013; Lv et al., 2016). The synthetic triterpenoid CDDO activates PPAR gamma to induce apoptosis in DLBCL cells (Ray et al., 2006). In DLBCL, PPAR gamma ligands regulate the expression of both mRNA and protein of GSK-3beta to promote apoptosis and beta-catenin degradation (J.-J. Liu et al., 2012). PPAR gamma ligands directly decrease WNT/beta-catenin pathway to downregulate expression of c-Myc and cyclin D1 and then inhibit tumor cell growth (Fujisawa et al., 2008; Lu and Carson, 2010). 


\section{Opposite interplay between WNT/beta-catenin pathway and PPAR gamma}

In several diseases, WNT/beta-catenin pathway and PPAR gamma act in an opposite manner such as cancers (Lecarpentier, Claes, Vallée, and Hébert, 2017a, 2017b; Vallée, Lecarpentier, Guillevin, and Vallée, 2017b) and neurodegenerative diseases (Lecarpentier and Vallée, 2016; Vallée and Lecarpentier, 2016; Vallée, Lecarpentier, Guillevin, and Vallée, 2017a). WNT/beta-catenin pathway and PPAR gamma interact through a TCF/LEF betacatenin domain and a catenin-binding domain within PPAR gamma (J. Liu et al., 2006; Lu and Carson, 2010; Sharma et al., 2004; Takada, Kouzmenko, and Kato, 2009). The stimulation of PPAR gamma can be involved by the downregulation of the WNT/ $\beta$-catenin pathway (Garcia-Gras et al., 2006) whereas PPAR gamma agonists can downregulate

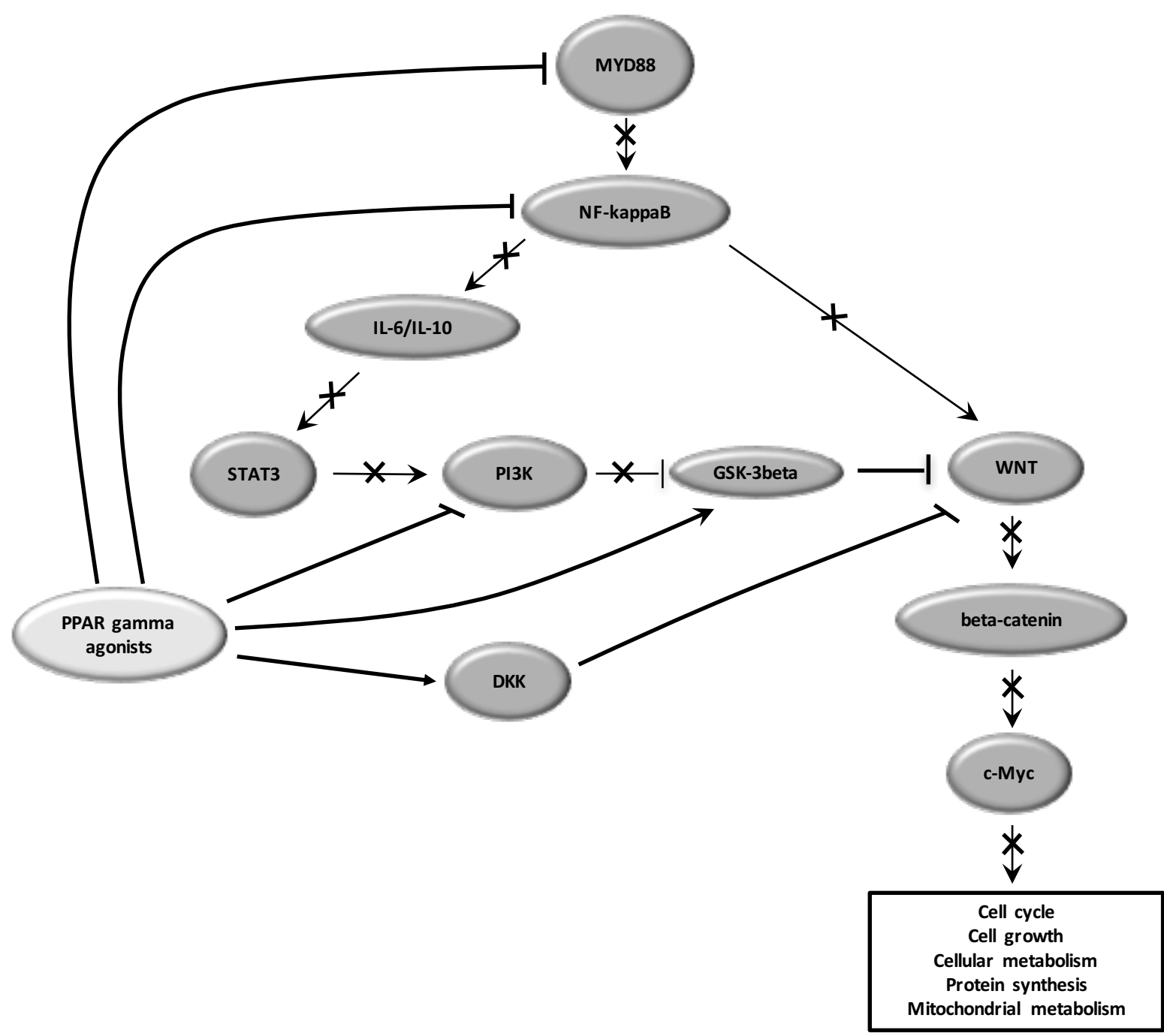

Figure 2. Actions of PPAR gamma in PCNSL. PPAR gamma agonists directly inhibit MYD88 expression and NF-kappaB activity, leading to reduce neuroinflammation. PPAR gamma agonists also decrease PI3K/Akt pathway whereas they activate GSK-3beta activity to inhibit WNT pathway. PPAR gamma agonists stimulate DKK, which downregulates WNT/beta-catenin pathway. Absence of WNT ligands prevents binding with FZD/LRP 5/6. The betacatenin destruction complex is formed and composed by APC, AXIN and GSK-3beta, which mediates proteasomal degradation of beta-catenin. Thus, cMyc is not activated. 
expression levels of beta-catenin in many cellular systems (Elbrecht et al., 1996; Fajas et al., 1997; Moldes et al., 2003). PPAR gamma agonists can be considered as neuroprotective agents and can promote synaptic plasticity through a WNT/betacatenin/PI3K/Akt pathway interaction (Farshbaf, Ghaedi, Shirani, and Nasr-Esfahani, 2014). The regulation of mesenchymal stem cell differentiation can also show the existence of this crosstalk (Xu et al., 2016).

Indeed, in many diseases beta-catenin signaling inhibits PPAR gamma expression (Drygiannakis et al., 2013; Farmer, 2005; Jeon et al., 2014; Kumar, Mundra, and Mahato, 2014; Lee et al., 2013; Qinghua Li et al., 2012; J. Liu and Farmer, 2004; Qian, Niu, Zhai, Zhou, and Zhou, 2012; Segel et al., 2003; Shim et al., 2014). PPAR gamma agonists are considered as interesting treatments through this crosstalk (Sabatino et al., 2014). Troglitazone, a PPAR gamma agonist, can diminish c-Myc levels, a WNT target gene (Akinyeke and Stewart, 2011). In intestinal fibrosis, the activation of WNT/betacatenin has been shown, and the use of PPAR gamma agonist can downregulate WNT/betacatenin pathway activation and then inhibit fibrosis formation (Di Gregorio et al., 2017). PPAR gamma agonists activate Dickkopf-1 (DKK1) activity, which downregulate the canonical WNT/beta-catenin pathway and then repress the differentiation of fibroblasts (Gustafson, Eliasson, and Smith, 2010). During adipogenesis in 3T3-L1 cells, PI3K/Akt pathway activation downregulates PPAR gamma expression (Prusty, Park, Davis, and Farmer, 2002). PI3K/Akt signaling inhibits PPAR gamma expression in adipocyte differentiation (S. Kim et al., 2010; X.D. Peng et al., 2003; H. H. Zhang et al., 2009). PI3K/Akt pathway phosphorylates GSK-3beta and then downregulates it, which negatively regulates PPAR gamma expression (Grimes and Jope, 2001; Ross et al., 1999). In adipocytes and 2T2-L1 preadipocytes, beta-catenin signaling, through the activation of Akt signaling, downregulates PPAR gamma expression (Huelsken and Behrens, 2002; Moldes et al., 2003). Moreover, inhibition of Akt pathway in 3T3-L1 cells activates PPAR gamma expression (H. J. Park et al., 2014). PPAR gamma agonists can decrease the activity of PI3K/Akt signaling pathway (Aljada, O'Connor, Fu, and Mousa, 2008; Goetze et al., 2002). Numerous inflammatory cytokines, chemokines, or intracellular signaling downregulates PPAR gamma expression, such as canonical WNT/beta-catenin pathway, TNFalpha, interleukin (IL)-1, and IL-13 (Simon et al., 2005; Tan et al., 2008; Yamasaki et al., 2004). The transcription factor COUP II is a canonical WNT target and downregulates PPAR gamma expression (Okamura et al., 2009). In adipocytes, adiponectin increases PPAR gamma expression and then downregulates LPS-induced NF-kappaB expression and IL-6 production (Ajuwon and Spurlock, 2005). Mesenchymal stem cell differentiation shows also a crosstalk between WNT pathway and PPAR gamma (Xu et al., 2016). Hepatic fatty acid metabolism, fatty acid oxidation, hepatic mitochondrial function and energy balance are regulated by the interaction between WNT/beta-catenin pathway and PPAR gamma (Gebhardt and Hovhannisyan, 2010; Lehwald et al., 2012; J. Liu et al., 2006). PPAR gamma is considered as a negative beta-catenin target gene (Ajmone-Cat et al., 2016; Jansson et al., 2005).

\section{Conclusion}

PCNSLs are angiocentric neoplasia which are infiltrative and extend beyond the primary lesion.

ABC-DLBCL subtype represents more than $90 \%$ of PCNSLs and is the most aggressive subtype with a cure rate of only $40 \%$. Therefore, it is essential to investigate the mechanisms underlying the development and progression of PCNSLs and to explore more effective therapeutic strategies.

In PCNSLs, the canonical WNT/beta-catenin pathway is upregulated while PPAR gamma is downregulated. These two systems act in an opposite manner. Activation of WNT/beta-catenin pathway leads to the transcription of genes involved in cell proliferation, mitochondrial metabolism, protein synthesis, and tumor growth, such as c-Myc (cf. Figure 1). c-Myc is considered as a key prognostic and predictive biomarker for survival in DLBCL, its expression is associated with worst survival rates.

In addition, STAT3 signaling pathway upregulates the expression and transcriptional activity of betacatenin. STAT3 is a tumor aggressiveness factor. MYD88 stimulates inflammation in ABC-DLBCL through the activation of NF-kappaB pathway. NFkappaB increases STAT3 pathway through the stimulation of IL-6 and/or IL-10 and directly increases WNT/beta-catenin pathway. STAT3 increases PI3K/Akt pathway, which inhibits GSK-3beta to activate WNT/beta-catenin pathway and thus allow beta-catenin accumulation, stabilization and nuclear translocation. Nuclear beta-catenin translocation activates WNT target genes, such as c-Myc. 
Canonical WNT/beta-catenin pathway activation induces inactivation of PPAR gamma leading to a decreased in insulin sensitivity and an increased in neuro-inflammation. PPAR gamma agonists induce the inhibition of several signaling pathways such as the NF-kappaB, STAT, WNT/beta-catenin and PI3K/ Akt pathways through the activation of GSK-3beta. PPAR gamma agonists may have a major negative key role in the regulation of progression of PCNSLs. The opposite interplay between WNT/beta-catenin signaling and PPAR gamma in PCNSLs provides a better understanding of the mechanisms underlying PCNSLs progression.

\section{Author contributions}

All authors listed, have made substantial, direct and intellectual contribution to the work, and approved it for publication.

\section{Conflict of interest statement}

The authors declare that the research was conducted in the absence of any commercial or financial relationship that could be construed as a potential conflict of interest.

\section{References}

Aberle, H., Bauer, A., Stappert, J., Kispert, A., and Kemler, R. (1997). $\beta$-catenin is a target for the ubiquitin-proteasome pathway. The EMBO Journal, 16(13), 3797-3804. https://doi.org/ 10.1093/emboj/16.13.3797

Abrey, L. E., DeAngelis, L. M., and Yahalom, J. (1998). Long-term survival in primary CNS lymphoma. Journal of Clinical Oncology: Official Journal of the American Society of Clinical Oncology, 16(3), 859-863. https://doi.org/10.1200/ JCO.1998.16.3.859

Ahmadian, M., Suh, J. M., Hah, N., Liddle, C., Atkins, A. R., Downes, M., and Evans, R. M. (2013). PPARy signaling and metabolism: the good, the bad and the future. Nature Medicine, 19(5), 557-566. https://doi.org/10.1038/nm.3159

Aho, R., Ekfors, T., Haltia, M., and Kalimo, H. (1993). Pathogenesis of primary central nervous system lymphoma: invasion of malignant lymphoid cells into and within the brain parenchyme. Acta Neuropathologica, 86(1), 71-76.

Ajmone-Cat, M. A., D'Urso, M. C., di Blasio, G., Brignone, M. S., De Simone, R., and Minghetti, L. (2016). Glycogen synthase kinase 3 is part of the molecular machinery regulating the adaptive response to LPS stimulation in microglial cells. Brain, Behavior, and Immunity, 55, 225-235. https://doi.org/10.1016/j.bbi.2015.11.012
Ajuwon, K. M., and Spurlock, M. E. (2005). Adiponectin inhibits LPS-induced NF-kappaB activation and IL-6 production and increases PPARgamma2 expression in adipocytes. American Journal of Physiology. Regulatory, Integrative and Comparative Physiology, 288(5), R1220-1225. https://doi.org/10.1152/ajpregu. 00397.2004

Akinyeke, T. O., and Stewart, L. V. (2011). Troglitazone suppresses c-Myc levels in human prostate cancer cells via a PPARy-independent mechanism. Cancer Biology and Therapy, 11(12), 1046-1058.

Akira, S., Nishio, Y., Inoue, M., Wang, X. J., Wei, S., Matsusaka, T., ... Kishimoto, T. (1994). Molecular cloning of APRF, a novel IFN-stimulated gene factor 3 p91-related transcription factor involved in the gp130-mediated signaling pathway. Cell, 77(1), 63-71.

Albanese, C., Wu, K., D'Amico, M., Jarrett, C., Joyce, D., Hughes, J., ... Pestell, R. G. (2003). IKKalpha regulates mitogenic signaling through transcriptional induction of cyclin D1 via Tcf. Molecular Biology of the Cell, 14(2), 585-599. https://doi.org/10.1091/mbc.02-06-0101

Al-Harthi, L. (2012). Wnt/ß-catenin and its Diverse Physiological Cell Signaling Pathways in Neurodegenerative and Neuropsychiatric Disorders. Journal of Neuroimmune Pharmacology, 7(4), 725-730. https://doi.org/ 10.1007/s11481-012-9412-x

Alizadeh, A. A., Eisen, M. B., Davis, R. E., Ma, C., Lossos, I. S., Rosenwald, A., ... Staudt, L. M. (2000). Distinct types of diffuse large B-cell lymphoma identified by gene expression profiling. Nature, 403(6769), 503-511. https://doi.org/ $10.1038 / 35000501$

Aljada, A., O'Connor, L., Fu, Y.-Y., and Mousa, S. A. (2008). PPAR gamma ligands, rosiglitazone and pioglitazone, inhibit bFGF- and VEGF-mediated angiogenesis. Angiogenesis, 11(4), 361-367. https://doi.org/10.1007/s10456-008-9118-0

Angers, S., and Moon, R. T. (2009). Proximal events in Wnt signal transduction. Nature Reviews Molecular Cell Biology. https://doi.org/10.1038/ nrm2717

Anson, M., Crain-Denoyelle, A.-M., Baud, V., Chereau, F., Gougelet, A., Terris, B., ... Couty, J.P. (2012). Oncogenic $\beta$-catenin triggers an inflammatory response that determines the aggressiveness of hepatocellular carcinoma in mice. The Journal of Clinical Investigation, 122(2), 586-599. https://doi.org/10.1172/JCI43937

Armanious, H., Gelebart, P., Mackey, J., Ma, Y., and Lai, R. (2010). STAT3 upregulates the protein 
expression and transcriptional activity of $\beta$-catenin in breast cancer. International Journal of Clinical and Experimental Pathology, 3(7), 654-664.

Basso, K., Saito, M., Sumazin, P., Margolin, A. A., Wang, K., Lim, W.-K., ... Dalla-Favera, R. (2010). Integrated biochemical and computational approach identifies BCL6 direct target genes controlling multiple pathways in normal germinal center B cells. Blood, 115(5), 975-984. https:// doi.org/10.1182/blood-2009-06-227017

Batchelor, T. T. (2016). Primary central nervous system lymphoma. Hematology. American Society of Hematology. Education Program, 2016(1), 379-385. https://doi.org/10.1182/ asheducation-2016.1.379

Ben-Neriah, Y., and Karin, M. (2011). Inflammation meets cancer, with NF-KB as the matchmaker. Nature Immunology, 12(8), 715-723. https:// doi.org/10.1038/ni.2060

Bhardwaj, A., Sethi, G., Vadhan-Raj, S., BuesoRamos, C., Takada, Y., Gaur, U., ... Aggarwal, B. B. (2007). Resveratrol inhibits proliferation, induces apoptosis, and overcomes chemoresistance through down-regulation of STAT3 and nuclear factor-kappaB-regulated antiapoptotic and cell survival gene products in human multiple myeloma cells. Blood, 109(6), 2293-2302. https://doi.org/10.1182/ blood-2006-02-003988

Bognar, M. K., Vincendeau, M., Erdmann, T., Seeholzer, T., Grau, M., Linnemann, J. R., ... Krappmann, D. (2016). Oncogenic CARMA1 couples NF-KB and $\beta$-catenin signaling in diffuse large B-cell lymphomas. Oncogene, 35(32), 4269-4281. https://doi.org/10.1038/onc.2015.493

Boi, M., Gaudio, E., Bonetti, P., Kwee, I., Bernasconi, E., Tarantelli, C., ... Bertoni, F. (2015). The BET Bromodomain Inhibitor OTX015 Affects Pathogenetic Pathways in Preclinical Bcell Tumor Models and Synergizes with Targeted Drugs. Clinical Cancer Research: An Official Journal of the American Association for Cancer Research, 21(7), 1628-1638. https://doi.org/ 10.1158/1078-0432.CCR-14-1561

Braggio, E., Van Wier, S., Ojha, J., McPhail, E., Asmann, Y. W., Egan, J., ... O'Neill, B. P. (2015). Genome-Wide Analysis Uncovers Novel Recurrent Alterations in Primary Central Nervous System Lymphomas. Clinical Cancer Research: An Official Journal of the American Association for Cancer Research, 21(17), 3986-3994. https:// doi.org/10.1158/1078-0432.CCR-14-2116

Brazil, D. P., Yang, Z.-Z., and Hemmings, B. A. (2004). Advances in protein kinase $B$ signalling: AKTion on multiple fronts. Trends in Biochemical
Sciences, 29(5), 233-242. https://doi.org/10.1016/ j.tibs.2004.03.006

Buss, H., Dörrie, A., Schmitz, M. L., Frank, R., Livingstone, M., Resch, K., and Kracht, M. (2004). Phosphorylation of serine 468 by GSK-3beta negatively regulates basal p65 NF-kappaB activity. The Journal of Biological Chemistry, 279(48), 49571-49574. https://doi.org/10.1074/ jbc.C400442200

Chapuy, B., Roemer, M. G. M., Stewart, C., Tan, Y., Abo, R. P., Zhang, L., ... Shipp, M. A. (2016). Targetable genetic features of primary testicular and primary central nervous system lymphomas. Blood, 127(7), 869-881. https://doi.org/10.1182/ blood-2015-10-673236

Chen, E., Staudt, L. M., and Green, A. R. (2012). Janus kinase deregulation in leukemia and lymphoma. Immunity, 36(4), 529-541. https:// doi.org/10.1016/j.immuni.2012.03.017

Chen, J., Alberts, I., and Li, X. (2014). Dysregulation of the IGF-I/PI3K/AKT/mTOR signaling pathway in autism spectrum disorders. International Journal of Developmental Neuroscience: The Official Journal of the International Society for Developmental Neuroscience, 35, 35-41. https:// doi.org/10.1016/j.ijdevneu.2014.03.006

Chisholm, K. M., Bangs, C. D., Bacchi, C. E., Molina-Kirsch, H., Cherry, A., and Natkunam, Y. (2015). Expression profiles of MYC protein and MYC gene rearrangement in lymphomas. The American Journal of Surgical Pathology, 39(3), 294-303. https://doi.org/10.1097/PAS. 0000000000000365

Ci, W., Polo, J. M., Cerchietti, L., Shaknovich, R., Wang, L., Yang, S. N., ... Melnick, A. (2009). The BCL6 transcriptional program features repression of multiple oncogenes in primary $B$ cells and is deregulated in DLBCL. Blood, 113(22), 5536-5548. https://doi.org/10.1182/ blood-2008-12-193037

Ciuffreda, L., Di Sanza, C., Incani, U. C., and Milella, M. (2010). The mTOR pathway: a new target in cancer therapy. Current Cancer Drug Targets, 10(5), 484-495.

Clevers, H., and Nusse, R. (2012). Wnt/ $\beta$-catenin signaling and disease. Cell, 149(6), 1192-1205. https://doi.org/10.1016/j.cell.2012.05.012

Cummins, E. P., Berra, E., Comerford, K. M., Ginouves, A., Fitzgerald, K. T., Seeballuck, F., ... Taylor, C. T. (2006). Prolyl hydroxylase-1 negatively regulates IkappaB kinase-beta, giving insight into hypoxia-induced NFkappaB activity. Proceedings of the National Academy of Sciences of the United States of America, 103(48), 
18154-18159. https://doi.org/10.1073/pnas . 0602235103

Dang, C. V., O'Donnell, K. A., Zeller, K. I., Nguyen, T., Osthus, R. C., and Li, F. (2006). The C-Myc target gene network. Seminars in Cancer Biology, 16(4), 253-264. https://doi.org/10.1016/ j.semcancer.2006.07.014

David, A., Arnaud, N., Fradet, M., Lascaux, H., OukMartin, C., Gachard, N., ... Faumont, N. (2017). cMyc dysregulation is a co-transforming event for nuclear factor-KB activated B cells. Haematologica, 102(5), 883-894. https://doi.org/ 10.3324/haematol.2016.156281

Davis, R. E., Brown, K. D., Siebenlist, U., and Staudt, L. M. (2001). Constitutive nuclear factor kappaB activity is required for survival of activated $\mathrm{B}$ cell-like diffuse large B cell lymphoma cells. The Journal of Experimental Medicine, 194(12), 1861-1874.

Davis, R. Eric, Ngo, V. N., Lenz, G., Tolar, P., Young, R. M., Romesser, P. B., ... Staudt, L. M. (2010). Chronic active B-cell-receptor signalling in diffuse large B-cell lymphoma. Nature, 463(7277), 88-92. https://doi.org/10.1038/nature08638

De Silva, N. S., and Klein, U. (2015). Dynamics of B cells in germinal centres. Nature Reviews. Immunology, 15(3), 137-148. https://doi.org/ 10.1038/nri3804

Decker, T., and Kovarik, P. (2000). Serine phosphorylation of STATs. Oncogene, 19(21), 2628-2637. https://doi.org/10.1038/sj.onc. 1203481

Delmore, J. E., Issa, G. C., Lemieux, M. E., Rahl, P. B., Shi, J., Jacobs, H. M., ... Mitsiades, C. S. (2011). BET bromodomain inhibition as a therapeutic strategy to target c-Myc. Cell, 146(6), 904-917. https://doi.org/10.1016/j.cell.2011.08.017

Di Gregorio, J., Sferra, R., Speca, S., Vetuschi, A., Dubuquoy, C., Desreumaux, P., ... Latella, G. (2017). Role of glycogen synthase kinase-3 $\beta$ and PPAR- $y$ on epithelial-to-mesenchymal transition in DSS-induced colorectal fibrosis. PloS One, 12(2), e0171093. https://doi.org/10.1371/journal.pone. 0171093

Ding, B. B., Yu, J. J., Yu, R. Y.-L., Mendez, L. M., Shaknovich, R., Zhang, Y., ... Ye, B. H. (2008). Constitutively activated STAT3 promotes cell proliferation and survival in the activated B-cell subtype of diffuse large B-cell lymphomas. Blood, 111(3), 1515-1523. https://doi.org/10.1182/ blood-2007-04-087734

Drygiannakis, I., Valatas, V., Sfakianaki, O., Bourikas, L., Manousou, P., Kambas, K., ... Kouroumalis, E. (2013). Proinflammatory cytokines induce crosstalk between colonic epithelial cells and subepithelial myofibroblasts: implication in intestinal fibrosis. Journal of Crohn's and Colitis, 7(4), 286-300. https://doi.org/10.1016/ j.crohns.2012.04.008

Dutton, A., Reynolds, G. M., Dawson, C. W., Young, L. S., and Murray, P. G. (2005). Constitutive activation of phosphatidyl-inositide 3 kinase contributes to the survival of Hodgkin's lymphoma cells through a mechanism involving Akt kinase and mTOR. The Journal of Pathology, 205(4), 498-506. https://doi.org/10.1002/path.1725

Duyao, M. P., Buckler, A. J., and Sonenshein, G. E. (1990). Interaction of an NF-kappa B-like factor with a site upstream of the c-myc promoter. Proceedings of the National Academy of Sciences of the United States of America, 87(12), 4727-4731.

Elbrecht, A., Chen, Y., Cullinan, C. A., Hayes, N., Leibowitz, M. d, Moller, D. E., and Berger, J. (1996). Molecular cloning, expression and characterization of human peroxisome proliferator activated receptors gamma 1 and gamma 2 . Biochemical and Biophysical Research Communications, 224(2), 431-437.

Fajas, L., Auboeuf, D., Raspé, E., Schoonjans, K., Lefebvre, A. M., Saladin, R., ... Auwerx, J. (1997). The organization, promoter analysis, and expression of the human PPARgamma gene. The Journal of Biological Chemistry, 272(30), 18779-18789.

Farmer, S. R. (2005). Regulation of PPARgamma activity during adipogenesis. International Journal of Obesity (2005), 29 Suppl 1, S13-16. https:// doi.org/10.1038/sj.ijo.0802907

Farshbaf, M. J., Ghaedi, K., Shirani, M., and NasrEsfahani, M. H. (2014). Peroxisome proliferator activated receptor gamma (PPARY) as a therapeutic target for improvement of cognitive performance in Fragile-X. Medical Hypotheses, 82(3), 291-294. https://doi.org/10.1016/j.mehy. 2013.12.012

Fillmore, G. C., Wang, Q., Carey, M. J., Kim, C.-H., Elenitoba-Johnson, K. S. J., and Lim, M. S. (2005). Expression of Akt (protein kinase B) and its isoforms in malignant lymphomas. Leukemia and Lymphoma, 46(12), 1765-1773. https:// doi.org/10.1080/10428190500159944

Fine, H. A., and Mayer, R. J. (1993). Primary central nervous system lymphoma. Annals of Internal Medicine, 119(11), 1093-1104.

Fujisawa, T., Nakajima, A., Fujisawa, N., Takahashi, H., Ikeda, I., Tomimoto, A., ... Blumberg, R. S. (2008). Peroxisome proliferator-activated receptor gamma (PPARgamma) suppresses colonic epithelial cell turnover and colon carcinogenesis 
through inhibition of the beta-catenin/T cell factor (TCF) pathway. Journal of Pharmacological Sciences, 106(4), 627-638.

Garcia-Gras, E., Lombardi, R., Giocondo, M. J., Willerson, J. T., Schneider, M. D., Khoury, D. S., and Marian, A. J. (2006). Suppression of canonical Wnt/beta-catenin signaling by nuclear plakoglobin recapitulates phenotype of arrhythmogenic right ventricular cardiomyopathy. The Journal of Clinical Investigation, 116(7), 2012-2021. https://doi.org/10.1172/JCI27751

Ge, X., Lv, X., Feng, L., Liu, X., and Wang, X. (2012). High expression and nuclear localization of $\beta$-catenin in diffuse large B-cell lymphoma. Molecular Medicine Reports, 5(6), 1433-1437. https://doi.org/10.3892/mmr.2012.835

Gebhardt, R., and Hovhannisyan, A. (2010). Organ patterning in the adult stage: the role of $\mathrm{Wnt} /$ betacatenin signaling in liver zonation and beyond. Developmental Dynamics: An Official Publication of the American Association of Anatomists, 239(1), 45-55. https://doi.org/10.1002/dvdy.22041

Ghosh, A. K., Kay, N. E., Secreto, C. R., and Shanafelt, T. D. (2009). Curcumin inhibits prosurvival pathways in chronic lymphocytic leukemia B cells and may overcome their stromal protection in combination with EGCG. Clinical Cancer Research: An Official Journal of the American Association for Cancer Research, 15(4), 1250-1258. https://doi.org/10.1158/10780432.CCR-08-1511

Goetze, S., Eilers, F., Bungenstock, A., Kintscher, U., Stawowy, P., Blaschke, F., ... Gräfe, M. (2002). PPAR activators inhibit endothelial cell migration by targeting Akt. Biochemical and Biophysical Research Communications, 293(5), 1431-1437. https://doi.org/10.1016/S0006-291X(02)00385-6

Grimes, C. A., and Jope, R. S. (2001). The multifaceted roles of glycogen synthase kinase 3 beta in cellular signaling. Progress in Neurobiology, 65(4), 391-426.

Gruetter, R. (2003). Glycogen: the forgotten cerebral energy store. Journal of Neuroscience Research, 74(2), 179-183. https://doi.org/10.1002/jnr.10785

Gustafson, B., Eliasson, B., and Smith, U. (2010). Thiazolidinediones increase the wingless-type MMTV integration site family (WNT) inhibitor Dickkopf-1 in adipocytes: a link with osteogenesis. Diabetologia, 53(3), 536-540. https://doi.org/ 10.1007/s00125-009-1615-1

Hardee, J., Ouyang, Z., Zhang, Y., Kundaje, A., Lacroute, P., and Snyder, M. (2013). STAT3 targets suggest mechanisms of aggressive tumorigenesis in diffuse large B-cell lymphoma.
G3 (Bethesda, Md.), 3(12), 2173-2185. https:// doi.org/10.1534/g3.113.007674

Heras-Sandoval, D., Pérez-Rojas, J. M., Hernández-Damián, J., and Pedraza-Chaverri, J. (2014). The role of PI3K/AKT/mTOR pathway in the modulation of autophagy and the clearance of protein aggregates in neurodegeneration. Cellular Signalling, 26(12), 2694-2701. https://doi.org/ 10.1016/j.cellsig.2014.08.019

Hirano, T., Ishihara, K., and Hibi, M. (2000). Roles of STAT3 in mediating the cell growth, differentiation and survival signals relayed through the IL-6 family of cytokine receptors. Oncogene, 19(21), 2548-2556. https://doi.org/10.1038/sj.onc. 1203551

Hnisz, D., Abraham, B. J., Lee, T. I., Lau, A., SaintAndré, V., Sigova, A. A., ... Young, R. A. (2013). Super-enhancers in the control of cell identity and disease. Cell, 155(4), 934-947. https://doi.org/ 10.1016/j.cell.2013.09.053

Horn, H., Ziepert, M., Becher, C., Barth, T. F. E., Bernd, H.-W., Feller, A. C., ... German HighGrade Non-Hodgkin Lymphoma Study Group. (2013). MYC status in concert with BCL2 and BCL6 expression predicts outcome in diffuse large B-cell lymphoma. Blood, 121(12), 2253-2263. https://doi.org/10.1182/blood-201206-435842

Hu, H., Wang, B., Borde, M., Nardone, J., Maika, S., Allred, L., ... Rao, A. (2006). Foxp1 is an essential transcriptional regulator of $\mathrm{B}$ cell development. Nature Immunology, 7(8), 819-826. https://doi.org/ 10.1038/ni1358

Huang, J., Nguyen-McCarty, M., Hexner, E. O., Danet-Desnoyers, G., and Klein, P. S. (2012). Maintenance of hematopoietic stem cells through regulation of Wnt and mTOR pathways. Nature Medicine, 18(12), 1778-1785. https://doi.org/ 10.1038/nm.2984

Huelsken, J., and Behrens, J. (2002). The Wnt signalling pathway. Journal of Cell Science, 115(Pt 21), 3977-3978.

Jansson, E. A., Are, A., Greicius, G., Kuo, I.-C., Kelly, D., Arulampalam, V., and Pettersson, S. (2005). The Wnt/beta-catenin signaling pathway targets PPARgamma activity in colon cancer cells. Proceedings of the National Academy of Sciences of the United States of America, 102(5), 1460-1465. https://doi.org/10.1073/pnas. 0405928102

Jeon, K.-I., Kulkarni, A., Woeller, C. F., Phipps, R. P., Sime, P. J., Hindman, H. B., and Huxlin, K. R. (2014). Inhibitory effects of PPARy ligands on TGF- $\beta 1$-induced corneal myofibroblast transformation. The American Journal of 
Pathology, 184(5), 1429-1445. https://doi.org/ 10.1016/j.ajpath.2014.01.026

Johnson, N. A., Slack, G. W., Savage, K. J., Connors, J. M., Ben-Neriah, S., Rogic, S., ... Gascoyne, R. D. (2012). Concurrent expression of MYC and BCL2 in diffuse large B-cell lymphoma treated with rituximab plus cyclophosphamide, doxorubicin, vincristine, and prednisone. Journal of Clinical Oncology: Official Journal of the American Society of Clinical Oncology, 30(28), 3452-3459. https://doi.org/10.1200/JCO. 2011.41.0985

Kang, S.-H., Yu, M. O., Park, K.-J., Chi, S.-G., Park, D.-H., and Chung, Y.-G. (2010). Activated STAT3 regulates hypoxia-induced angiogenesis and cell migration in human glioblastoma. Neurosurgery, 67(5), 1386-1395; discussion 1395. https:// doi.org/10.1227/NEU.0b013e3181f1c0cd

Karin, M. (2009). NF-kappaB as a critical link between inflammation and cancer. Cold Spring Harbor Perspectives in Biology, 1(5), a000141. https://doi.org/10.1101/cshperspect.a000141

Karube, K., and Campo, E. (2015). MYC alterations in diffuse large B-cell lymphomas. Seminars in Hematology, 52(2), 97-106. https://doi.org/ 10.1053/j.seminhematol.2015.01.009

Katoh, M., Igarashi, M., Fukuda, H., Nakagama, H., and Katoh, M. (2013). Cancer genetics and genomics of human FOX family genes. Cancer Letters, 328(2), 198-206. https://doi.org/10.1016/ j.canlet.2012.09.017

Kim, H., Yoo, S. B., Sun, P., Jin, Y., Jheon, S., Lee, C. T., and Chung, J.-H. (2013). Alteration of the ECadherin/ $\beta$-Catenin Complex is an Independent Poor Prognostic Factor in Lung Adenocarcinoma. Korean Journal of Pathology, 47(1), 44-51. https:// doi.org/10.4132/KoreanJPathol.2013.47.1.44

Kim, S., Ha, J. M., Yun, S. J., Kim, E. K., Chung, S. W., Hong, K. W., ... Bae, S. S. (2010). Transcriptional activation of peroxisome proliferatoractivated receptor-gamma requires activation of both protein kinase $A$ and Akt during adipocyte differentiation. Biochemical and Biophysical Research Communications, 399(1), 55-59. https:// doi.org/10.1016/j.bbrc.2010.07.038

Kiuchi, N., Nakajima, K., Ichiba, M., Fukada, T., Narimatsu, M., Mizuno, K., ... Hirano, T. (1999). STAT3 is required for the gp130-mediated full activation of the c-myc gene. The Journal of Experimental Medicine, 189(1), 63-73.

Kluk, M. J., Chapuy, B., Sinha, P., Roy, A., Dal Cin, P., Neuberg, D. S., ... Rodig, S. J. (2012). Immunohistochemical detection of MYC-driven diffuse large B-cell lymphomas. PloS One, 7(4), e33813. https://doi.org/10.1371/journal.pone. 0033813

Knittel, G., Liedgens, P., Korovkina, D., Pallasch, C. P., and Reinhardt, H. C. (2016). Rewired NFKB signaling as a potentially actionable feature of activated B-cell-like diffuse large B-cell lymphoma. European Journal of Haematology, 97(6), 499-510. https://doi.org/10.1111/ejh.12792

Koch, R., Demant, M., Aung, T., Diering, N., Cicholas, A., Chapuy, B., ... Wulf, G. G. (2014). Populational equilibrium through exosomemediated Wnt signaling in tumor progression of diffuse large B-cell lymphoma. Blood, 123(14), 2189-2198. https://doi.org/10.1182/ blood-2013-08-523886

Koon, H. B., Ippolito, G. C., Banham, A. H., and Tucker, P. W. (2007). FOXP1: a potential therapeutic target in cancer. Expert Opinion on Therapeutic Targets, 11(7), 955-965. https:// doi.org/10.1517/14728222.11.7.955

Kossakowska, A. E., Edwards, D. R., Prusinkiewicz, C., Zhang, M. C., Guo, D., Urbanski, S. J., ... Janowska-Wieczorek, A. (1999). Interleukin-6 regulation of matrix metalloproteinase (MMP-2 and MMP-9) and tissue inhibitor of metalloproteinase (TIMP-1) expression in malignant non-Hodgkin's lymphomas. Blood, 94(6), 2080-2089.

Kumar, V., Mundra, V., and Mahato, R. I. (2014). Nanomedicines of Hedgehog inhibitor and PPARY agonist for treating liver fibrosis. Pharmaceutical Research, 31(5), 1158-1169. https://doi.org/ 10.1007/s11095-013-1239-5

Kuphal, S., Poser, I., Jobin, C., Hellerbrand, C., and Bosserhoff, A. K. (2004). Loss of E-cadherin leads to upregulation of NFkappaB activity in malignant melanoma. Oncogene, 23(52), 8509-8519. https:// doi.org/10.1038/sj.onc.1207831

Lakatos, H. F., Thatcher, T. H., Kottmann, R. M., Garcia, T. M., Phipps, R. P., and Sime, P. J. (2007). The Role of PPARs in Lung Fibrosis. PPAR Research, 2007, 71323. https://doi.org/ 10.1155/2007/71323

Lam, L. T., Wright, G., Davis, R. E., Lenz, G., Farinha, P., Dang, L., ... Staudt, L. M. (2008). Cooperative signaling through the signal transducer and activator of transcription 3 and nuclear factor-\{kappa\}B pathways in subtypes of diffuse large B-cell lymphoma. Blood, 111(7), 3701-3713. https://doi.org/10.1182/ blood-2007-09-111948

Lamberti, C., Lin, K. M., Yamamoto, Y., Verma, U., Verma, I. M., Byers, S., and Gaynor, R. B. (2001). Regulation of beta-catenin function by the IkappaB kinases. The Journal of Biological 
Chemistry, 276(45), 42276-42286. https://doi.org/ 10.1074/jbc.M104227200

Lambiv, W. L., Vassallo, I., Delorenzi, M., Shay, T., Diserens, A.-C., Misra, A., ... Hegi, M. E. (2011). The Wnt inhibitory factor 1 (WIF1) is targeted in glioblastoma and has a tumor suppressing function potentially by induction of senescence. Neuro-Oncology, 13(7), 736-747. https://doi.org/ 10.1093/neuonc/nor036

Lecarpentier, Y., Claes, V., Duthoit, G., and Hébert, J.-L. (2014). Circadian rhythms, Wnt/beta-catenin pathway and PPAR alpha/gamma profiles in diseases with primary or secondary cardiac dysfunction. Frontiers in Physiology, 5, 429. https://doi.org/10.3389/fphys.2014.00429

Lecarpentier, Y., Claes, V., Vallée, A., and Hébert, J.-L. (2017a). Interactions between PPAR Gamma and the Canonical Wnt/Beta-Catenin Pathway in Type 2 Diabetes and Colon Cancer. PPAR Research, 2017, 1-9. https://doi.org/ $10.1155 / 2017 / 5879090$

Lecarpentier, Y., Claes, V., Vallée, A., and Hébert, J.-L. (2017b). Thermodynamics in cancers: opposing interactions between PPAR gamma and the canonical WNT/beta-catenin pathway. Clinical and Translational Medicine, 6(1), 14. https:// doi.org/10.1186/s40169-017-0144-7

Lecarpentier, Y., and Vallée, A. (2016). Opposite Interplay between PPAR Gamma and Canonical Wnt/Beta-Catenin Pathway in Amyotrophic Lateral Sclerosis. Frontiers in Neurology, 7, 100. https:// doi.org/10.3389/fneur.2016.00100

Lee, Y., Kim, S. H., Lee, Y. J., Kang, E. S., Lee, B.W., Cha, B. S., ... Lee, H. C. (2013). Transcription factor Snail is a novel regulator of adipocyte differentiation via inhibiting the expression of peroxisome proliferator-activated receptor $\mathrm{Y}$. Cellular and Molecular Life Sciences: CMLS, 70(20), 3959-3971. https://doi.org/10.1007/ s00018-013-1363-8

Lehwald, N., Tao, G.-Z., Jang, K. Y., Papandreou, I., Liu, B., Liu, B., ... Sylvester, K. G. (2012). ßCatenin regulates hepatic mitochondrial function and energy balance in mice. Gastroenterology, 143(3), 754-764. https://doi.org/10.1053/j.gastro. 2012.05.048

Lenz, G., Wright, G., Dave, S. S., Xiao, W., Powell, J., Zhao, H., ... Lymphoma/Leukemia Molecular Profiling Project. (2008). Stromal gene signatures in large-B-cell lymphomas. The New England Journal of Medicine, 359(22), 2313-2323. https:// doi.org/10.1056/NEJMoa0802885

Lenz, Georg, and Staudt, L. M. (2010). Aggressive lymphomas. The New England Journal of
Medicine, 362(15), 1417-1429. https://doi.org/ 10.1056/NEJMra0807082

Levy, D. E., and Lee, C. (2002). What does Stat3 do? The Journal of Clinical Investigation, 109(9), 1143-1148. https://doi.org/10.1172/JCI15650

Li, G.-H., Wei, H., Lv, S.-Q., Ji, H., and Wang, D.-L. (2010). Knockdown of STAT3 expression by RNAi suppresses growth and induces apoptosis and differentiation in glioblastoma stem cells. International Journal of Oncology, 37(1), 103-110.

Li, Qinghua, Yan, Z., Li, F., Lu, W., Wang, J., and Guo, C. (2012). The improving effects on hepatic fibrosis of interferon-y liposomes targeted to hepatic stellate cells. Nanotechnology, 23(26), 265101. https:// doi.org/10.1088/0957-4484/23/26/265101

$\mathrm{Li}$, Qiutang, and Verma, I. M. (2002). NF-kappaB regulation in the immune system. Nature Reviews. Immunology, 2(10), 725-734. https:// doi.org/10.1038/nri910

Li, X., Du, J., Xu, S., Lin, X., and Ling, Z. (2013). Peroxisome proliferator-activated receptor- $y$ agonist rosiglitazone reduces secondary damage in experimental spinal cord injury. The Journal of International Medical Research, 41(1), 153-161. https://doi.org/10.1177/0300060513476601

Lin, S.-C., Lo, Y.-C., and Wu, H. (2010). Helical assembly in the MyD88-IRAK4-IRAK2 complex in TLR/IL-1R signalling. Nature, 465(7300), 885-890. https://doi.org/10.1038/nature09121

Lin, Y., Wong, K., and Calame, K. (1997). Repression of c-myc transcription by Blimp-1, an inducer of terminal B cell differentiation. Science (New York, N.Y.), 276(5312), 596-599.

Liu, J., and Farmer, S. R. (2004). Regulating the balance between peroxisome proliferatoractivated receptor gamma and beta-catenin signaling during adipogenesis. A glycogen synthase kinase 3beta phosphorylation-defective mutant of beta-catenin inhibits expression of a subset of adipogenic genes. The Journal of Biological Chemistry, 279(43), 45020-45027. https://doi.org/10.1074/jbc.M407050200

Liu, J., Wang, H., Zuo, Y., and Farmer, S. R. (2006). Functional interaction between peroxisome proliferator-activated receptor gamma and betacatenin. Molecular and Cellular Biology, 26(15), 5827-5837. https://doi.org/10.1128/MCB.00441-06 Liu, J.-J., Dai, X.-J., Xu, Y., Liu, P.-Q., Zhang, Y., Liu, X.-D., ... Huang, H.-Q. (2012). Inhibition of lymphoma cell proliferation by peroxisomal proliferator-activated receptor-y ligands via Wnt signaling pathway. Cell Biochemistry and Biophysics, 62(1), 19-27. https://doi.org/10.1007/ s12013-011-9253-x 
Logan, C. Y., and Nusse, R. (2004). The Wnt signaling pathway in development and disease. Annual Review of Cell and Developmental Biology, 20, 781-810. https://doi.org/10.1146/ annurev.cellbio.20.010403.113126

Lu, D., and Carson, D. A. (2010). Repression of beta-catenin signaling by PPAR gamma ligands. European Journal of Pharmacology, 636(1-3), 198-202. https://doi.org/10.1016/j.ejphar. 2010.03.010

Lv, F.-H., Yin, H.-L., He, Y.-Q., Wu, H.-M., Kong, J., Chai, X.-Y., and Zhang, S.-R. (2016). Effects of curcumin on the apoptosis of cardiomyocytes and the expression of NF-KB, PPAR- $\mathrm{Y}$ and $\mathrm{Bcl}-2$ in rats with myocardial infarction injury. Experimental and Therapeutic Medicine, 12(6), 3877-3884. https://doi.org/10.3892/etm.2016.3858

Ma, B., and Hottiger, M. O. (2016). Crosstalk between Wnt/B-Catenin and NF-KB Signaling Pathway during Inflammation. Frontiers in Immunology, 7, 378. https://doi.org/10.3389/ fimmu.2016.00378

Meyer, N., and Penn, L. Z. (2008). Reflecting on 25 years with MYC. Nature Reviews. Cancer, 8(12), 976-990. https://doi.org/10.1038/nrc2231

Michaud-Levesque, J., Bousquet-Gagnon, N., and Béliveau, R. (2012). Quercetin abrogates IL-6/ STAT3 signaling and inhibits glioblastoma cell line growth and migration. Experimental Cell Research, 318(8), 925-935. https://doi.org/ 10.1016/j.yexcr.2012.02.017

Moldes, M., Zuo, Y., Morrison, R. F., Silva, D., Park, B.-H., Liu, J., and Farmer, S. R. (2003). Peroxisome-proliferator-activated receptor gamma suppresses $\mathrm{Wnt} /$ beta-catenin signalling during adipogenesis. The Biochemical Journal, 376(Pt 3), 607-613. https://doi.org/10.1042/ BJ20030426

Murphy, D. J., Junttila, M. R., Pouyet, L., Karnezis, A., Shchors, K., Bui, D. A., ... Evan, G. I. (2008). Distinct thresholds govern Myc's biological output in vivo. Cancer Cell, 14(6), 447-457. https:// doi.org/10.1016/j.ccr.2008.10.018

Nahar, R., Ramezani-Rad, P., Mossner, M., Duy, C., Cerchietti, L., Geng, H., .. Müschen, M. (2011). Pre-B cell receptor-mediated activation of BCL6 induces pre-B cell quiescence through transcriptional repression of MYC. Blood, 118(15), 4174-4178. https://doi.org/10.1182/ blood-2011-01-331181

Nejak-Bowen, K., Kikuchi, A., and Monga, S. P. S. (2013). Beta-catenin-NF-KB interactions in murine hepatocytes: a complex to die for. Hepatology (Baltimore, Md.), 57(2), 763-774. https://doi.org/ 10.1002/hep.26042
Ngo, V. N., Young, R. M., Schmitz, R., Jhavar, S., Xiao, W., Lim, K.-H., ... Staudt, L. M. (2011). Oncogenically active MYD88 mutations in human lymphoma. Nature, 470(7332), 115-119. https:// doi.org/10.1038/nature09671

Noubissi, F. K., Elcheva, I., Bhatia, N., Shakoori, A., Ougolkov, A., Liu, J., ... Spiegelman, V. S. (2006). CRD-BP mediates stabilization of betaTrCP1 and c-myc mRNA in response to beta-catenin signalling. Nature, 441(7095), 898-901. https:// doi.org/10.1038/nature04839

Oestreich, K. J., Mohn, S. E., and Weinmann, A. S. (2012). Molecular mechanisms that control the expression and activity of $\mathrm{Bcl}-6$ in $\mathrm{TH} 1$ cells to regulate flexibility with a TFH-like gene profile. Nature Immunology, 13(4), 405-411. https:// doi.org/10.1038/ni.2242

Oguma, K., Oshima, H., Aoki, M., Uchio, R., Naka, K., Nakamura, S., ... Oshima, M. (2008). Activated macrophages promote Wnt signalling through tumour necrosis factor-alpha in gastric tumour cells. The EMBO Journal, 27(12), 1671-1681. https://doi.org/10.1038/emboj. 2008.105

Okamura, M., Kudo, H., Wakabayashi, K., Tanaka, T., Nonaka, A., Uchida, A., ... Sakai, J. (2009). COUP-TFII acts downstream of Wnt/beta-catenin signal to silence PPARgamma gene expression and repress adipogenesis. Proceedings of the National Academy of Sciences of the United States of America, 106(14), 5819-5824. https:// doi.org/10.1073/pnas.0901676106

O'Shea, J. J. (1997). Jaks, STATs, cytokine signal transduction, and immunoregulation: are we there yet? Immunity, 7(1), 1-11.

Ott, G., Rosenwald, A., and Campo, E. (2013). Understanding MYC-driven aggressive B-cell lymphomas: pathogenesis and classification. Hematology. American Society of Hematology. Education Program, 2013, 575-583. https:// doi.org/10.1182/asheducation-2013.1.575

Padilla, J., Kaur, K., Cao, H. J., Smith, T. J., and Phipps, R. P. (2000). Peroxisome proliferator activator receptor-gamma agonists and 15-deoxyDelta(12,14)(12,14)-PGJ(2) induce apoptosis in normal and malignant B-lineage cells. Journal of Immunology (Baltimore, Md.: 1950), 165(12), 6941-6948.

Padilla, Josué, Leung, E., and Phipps, R. P. (2002). Human B lymphocytes and B lymphomas express PPAR-gamma and are killed by PPAR-gamma agonists. Clinical Immunology (Orlando, Fla.), 103(1), 22-33. https://doi.org/10.1006/clim. 2001.5181 
Park, E. J., Park, S. Y., Joe, E., and Jou, I. (2003). $15 d-P G J 2$ and rosiglitazone suppress Janus kinase-STAT inflammatory signaling through induction of suppressor of cytokine signaling 1 (SOCS1) and SOCS3 in glia. The Journal of Biological Chemistry, 278(17), 14747-14752. https://doi.org/10.1074/jbc.M210819200

Park, H. J., Yun, J., Jang, S.-H., Kang, S. N., Jeon, B.-S., Ko, Y.-G., ... Cho, J.-H. (2014). Coprinus comatus cap inhibits adipocyte differentiation via regulation of PPARy and Akt signaling pathway. PloS One, 9(9), e105809. https://doi.org/10.1371/ journal.pone.0105809

Park, K. S., Lee, R. D., Kang, S.-K., Han, S. Y., Park, K. L., Yang, K. H., ... Hong, J. T. (2004). Neuronal differentiation of embryonic midbrain cells by upregulation of peroxisome proliferatoractivated receptor-gamma via the JNK-dependent pathway. Experimental Cell Research, 297(2), 424-433. https://doi.org/10.1016/j.yexcr. 2004.03.034

Pasparakis, M. (2009). Regulation of tissue homeostasis by NF-kappaB signalling: implications for inflammatory diseases. Nature Reviews. Immunology, 9(11), 778-788. https:// doi.org/10.1038/nri2655

Pasqualucci, L., and Zhang, B. (2016). Genetic drivers of NF-KB deregulation in diffuse large Bcell lymphoma. Seminars in Cancer Biology, 39, 26-31. https://doi.org/10.1016/j.semcancer. 2016.08.001

Paydas, S. (2017). Primary central nervous system lymphoma: essential points in diagnosis and management. Medical Oncology (Northwood, London, England), 34(4), 61. https://doi.org/ 10.1007/s12032-017-0920-7

Pedersen, M. Ø., Gang, A. O., Poulsen, T. S., Knudsen, H., Lauritzen, A. F., Nielsen, S. L., ... Nørgaard, P. (2014). MYC translocation partner gene determines survival of patients with large Bcell lymphoma with MYC- or double-hit MYC/ BCL2 translocations. European Journal of Haematology, 92(1), 42-48. https://doi.org/ 10.1111/ejh.12212

Peng, X.-D., Xu, P.-Z., Chen, M.-L., HahnWindgassen, A., Skeen, J., Jacobs, J., ... Hay, N. (2003). Dwarfism, impaired skin development, skeletal muscle atrophy, delayed bone development, and impeded adipogenesis in mice lacking Akt1 and Akt2. Genes and Development, 17(11), 1352-1365. https://doi.org/10.1101/gad. 1089403

Peng, Z.-H., Wan, D.-S., Li, L.-R., Chen, G., Lu, Z.H., Wu, X.-J., .. Pan, Z.-Z. (2011). Expression of COX-2, MMP-2 and VEGF in stage II and III colorectal cancer and the clinical significance. Hepato-Gastroenterology, 58(106), 369-376.

Perry, A. M., Alvarado-Bernal, Y., Laurini, J. A., Smith, L. M., Slack, G. W., Tan, K. L., ... Weisenburger, D. D. (2014). MYC and BCL2 protein expression predicts survival in patients with diffuse large B-cell lymphoma treated with rituximab. British Journal of Haematology, 165(3), 382-391. https://doi.org/10.1111/bjh.12763

Pham, L. V., Tamayo, A. T., Yoshimura, L. C., Lo, P., Terry, N., Reid, P. S., and Ford, R. J. (2002). A CD40 Signalosome anchored in lipid rafts leads to constitutive activation of NF-kappaB and autonomous cell growth in B cell lymphomas. Immunity, 16(1), 37-50.

Pillai, R. K., Sathanoori, M., Van Oss, S. B., and Swerdlow, S. H. (2013). Double-hit B-cell lymphomas with BCL6 and MYC translocations are aggressive, frequently extranodal lymphomas distinct from BCL2 double-hit B-cell lymphomas. The American Journal of Surgical Pathology, 37(3), 323-332. https://doi.org/10.1097/PAS. Ob013e31826cebad

Prathab Balaji, S., Vijay Chand, C., Justin, A., and Ramanathan, M. (2015). Telmisartan mediates anti-inflammatory and not cognitive function through PPAR-y agonism via SARM and MyD88 signaling. Pharmacology, Biochemistry, and Behavior, 137, 60-68. https://doi.org/10.1016/ j.pbb.2015.08.007

Prusty, D., Park, B.-H., Davis, K. E., and Farmer, S. R. (2002). Activation of MEK/ERK signaling promotes adipogenesis by enhancing peroxisome proliferator-activated receptor gamma (PPARgamma ) and C/EBPalpha gene expression during the differentiation of 3T3-L1 preadipocytes. The Journal of Biological Chemistry, 277(48), 46226-46232. https://doi.org/10.1074/ jbc.M207776200

Qian, J., Niu, M., Zhai, X., Zhou, Q., and Zhou, Y. (2012). $\beta$-Catenin pathway is required for TGF- $\beta 1$ inhibition of PPARy expression in cultured hepatic stellate cells. Pharmacological Research, 66(3), 219-225. https://doi.org/10.1016/j.phrs. 2012.06.003

Qiang, Y.-W., Endo, Y., Rubin, J. S., and Rudikoff, S. (2003). Wnt signaling in B-cell neoplasia. Oncogene, 22(10), 1536-1545. https://doi.org/ 10.1038/sj.onc.1206239

Ray, D. M., Akbiyik, F., Bernstein, S. H., and Phipps, R. P. (2005). CD40 engagement prevents peroxisome proliferator-activated receptor gamma agonist-induced apoptosis of $B$ lymphocytes and B lymphoma cells by an NF-kappaB-dependent 
mechanism. Journal of Immunology (Baltimore, Md.: 1950), 174(7), 4060-4069.

Ray, D. M., Bernstein, S. H., and Phipps, R. P. (2004). Human multiple myeloma cells express peroxisome proliferator-activated receptor gamma and undergo apoptosis upon exposure to PPARgamma ligands. Clinical Immunology (Orlando, Fla.), 113(2), 203-213. https://doi.org/ 10.1016/j.clim.2004.06.011

Ray, D. M., Morse, K. M., Hilchey, S. P., Garcia, T. M., Felgar, R. E., Maggirwar, S. B., ... Bernstein, S. H. (2006). The novel triterpenoid 2-cyano-3,12dioxooleana-1,9-dien-28-oic acid (CDDO) induces apoptosis of human diffuse large B-cell lymphoma cells through a peroxisome proliferator-activated receptor gamma-independent pathway. Experimental Hematology, 34(9), 1202-1211. https://doi.org/10.1016/j.exphem.2006.04.026

Reya, T., O'Riordan, M., Okamura, R., Devaney, E., Willert, K., Nusse, R., and Grosschedl, R. (2000). Wnt signaling regulates $\mathrm{B}$ lymphocyte proliferation through a LEF-1 dependent mechanism. Immunity, 13(1), 15-24.

Ricote, M., and Glass, C. K. (2007). PPARs and molecular mechanisms of transrepression. Biochimica Et Biophysica Acta, 1771(8), 926-935. https://doi.org/10.1016/j.bbalip.2007.02.013

Roschewski, M., Staudt, L. M., and Wilson, W. H. (2014). Diffuse large B-cell lymphoma-treatment approaches in the molecular era. Nature Reviews. Clinical Oncology, 11(1), 12-23. https://doi.org/ 10.1038/nrclinonc.2013.197

Ross, S. E., Erickson, R. L., Hemati, N., and MacDougald, O. A. (1999). Glycogen synthase kinase 3 is an insulin-regulated C/EBPalpha kinase. Molecular and Cellular Biology, 19(12), 8433-8441.

Rudelius, M., Pittaluga, S., Nishizuka, S., Pham, T. H.-T., Fend, F., Jaffe, E. S., ... Raffeld, M. (2006). Constitutive activation of Akt contributes to the pathogenesis and survival of mantle cell lymphoma. Blood, 108(5), 1668-1676. https:// doi.org/10.1182/blood-2006-04-015586

Rui, L., Drennan, A. C., Ceribelli, M., Zhu, F., Wright, G. W., Huang, D. W., ... Staudt, L. M. (2016). Epigenetic gene regulation by Janus kinase 1 in diffuse large B-cell lymphoma. Proceedings of the National Academy of Sciences of the United States of America, 113(46), E7260-E7267. https:// doi.org/10.1073/pnas.1610970113

Rui, L., Emre, N. C. T., Kruhlak, M. J., Chung, H.-J., Steidl, C., Slack, G., ... Staudt, L. M. (2010). Cooperative epigenetic modulation by cancer amplicon genes. Cancer Cell, 18(6), 590-605. https://doi.org/10.1016/j.ccr.2010.11.013
Sabatino, L., Pancione, M., Votino, C., Colangelo, T., Lupo, A., Novellino, E., ... Colantuoni, V. (2014). Emerging role of the $\beta$ catenin-PPARY axis in the pathogenesis of colorectal cancer. World Journal of Gastroenterology, 20(23), 7137-7151. https:// doi.org/10.3748/wjg.v20.i23.7137

Saegusa, M., Hashimura, M., Kuwata, T., Hamano, M., and Okayasu, I. (2007). Crosstalk between NF-kappaB/p65 and beta-catenin/TCF4/p300 signalling pathways through alterations in GSK-3beta expression during trans-differentiation of endometrial carcinoma cells. The Journal of Pathology, 213(1), 35-45. https://doi.org/10.1002/ path.2198

Sagardoy, A., Martinez-Ferrandis, J. I., Roa, S., Bunting, K. L., Aznar, M. A., Elemento, O., ... Martinez-Climent, J. A. (2013). Downregulation of FOXP1 is required during germinal center B-cell function. Blood, 121(21), 4311-4320. https:// doi.org/10.1182/blood-2012-10-462846

Sarin, S., and Bernath, A. (2008). Turcot syndrome (glioma polyposis): a case report. Southern Medical Journal, 101(12), 1273-1274. https:// doi.org/10.1097/SMJ.0b013e3181883853

Scholz, C. C., Cavadas, M. A. S., Tambuwala, M. M., Hams, E., Rodríguez, J., von Kriegsheim, A., ... Taylor, C. T. (2013). Regulation of IL-1 $\beta$ induced NF-KB by hydroxylases links key hypoxic and inflammatory signaling pathways. Proceedings of the National Academy of Sciences of the United States of America, 110(46), 18490-18495. https://doi.org/10.1073/pnas. 1309718110

Schuringa, J. J., Schepers, H., Vellenga, E., and Kruijer, W. (2001). Ser727-dependent transcriptional activation by association of p300 with STAT3 upon IL-6 stimulation. FEBS Letters, 495(1-2), 71-76.

Scuto, A., Kujawski, M., Kowolik, C., Krymskaya, L., Wang, L., Weiss, L. M., ... Jove, R. (2011). STAT3 inhibition is a therapeutic strategy for $A B C$-like diffuse large B-cell lymphoma. Cancer Research, 71(9), 3182-3188. https://doi.org/ 10.1158/0008-5472.CAN-10-2380

Segel, M. J., Izbicki, G., Cohen, P. Y., Or, R., Christensen, T. G., Wallach-Dayan, S. B., and Breuer, R. (2003). Role of interferon-gamma in the evolution of murine bleomycin lung fibrosis. American Journal of Physiology. Lung Cellular and Molecular Physiology, 285(6), L1255-1262. https://doi.org/10.1152/ajplung.00303.2002

Shaffer, A. L., Rosenwald, A., and Staudt, L. M. (2002). Lymphoid malignancies: the dark side of B-cell differentiation. Nature Reviews. 
Immunology, 2(12), 920-932. https://doi.org/ 10.1038/nri953

Shaffer, A. L., Yu, X., He, Y., Boldrick, J., Chan, E. P., and Staudt, L. M. (2000). BCL-6 represses genes that function in lymphocyte differentiation, inflammation, and cell cycle control. Immunity, 13(2), 199-212.

Shaffer, Arthur L., Young, R. M., and Staudt, L. M. (2012). Pathogenesis of human B cell lymphomas. Annual Review of Immunology, 30, 565-610. https://doi.org/10.1146/annurevimmunol-020711-075027

Shair, K. H. Y., Bendt, K. M., Edwards, R. H., Bedford, E. C., Nielsen, J. N., and Raab-Traub, N. (2007). EBV latent membrane protein 1 activates Akt, NFkappaB, and Stat3 in B cell lymphomas. PLoS Pathogens, 3(11), e166. https://doi.org/ 10.1371/journal.ppat.0030166

Sharma, C., Pradeep, A., Wong, L., Rana, A., and Rana, B. (2004). Peroxisome proliferatoractivated receptor gamma activation can regulate beta-catenin levels via a proteasome-mediated and adenomatous polyposis coli-independent pathway. The Journal of Biological Chemistry, 279(34), 35583-35594. https://doi.org/10.1074/ jbc.M403143200

Sheiness, D., Fanshier, L., and Bishop, J. M. (1978). Identification of nucleotide sequences which may encode the oncogenic capacity of avian retrovirus MC29. Journal of Virology, 28(2), 600-610.

Sherry, M. M., Reeves, A., Wu, J. K., and Cochran, B. H. (2009). STAT3 is required for proliferation and maintenance of multipotency in glioblastoma stem cells. Stem Cells (Dayton, Ohio), 27(10), 2383-2392. https://doi.org/10.1002/stem. 185

Shim, C. Y., Song, B.-W., Cha, M.-J., Hwang, K.-C., Park, S., Hong, G.-R., ... Chung, N. (2014). Combination of a peroxisome proliferatoractivated receptor-gamma agonist and an angiotensin II receptor blocker attenuates myocardial fibrosis and dysfunction in type 2 diabetic rats. Journal of Diabetes Investigation, 5(4), 362-371. https://doi.org/10.1111/jdi.12153

Simon, M. F., Daviaud, D., Pradère, J. P., Grès, S., Guigné, C., Wabitsch, M., ... Saulnier-Blache, J. S. (2005). Lysophosphatidic acid inhibits adipocyte differentiation via lysophosphatidic acid 1 receptor-dependent down-regulation of peroxisome proliferator-activated receptor gamma2. The Journal of Biological Chemistry, 280(15), 14656-14662. https://doi.org/10.1074/ jbc.M412585200

Spiegelman, V. S., Slaga, T. J., Pagano, M., Minamoto, T., Ronai, Z., and Fuchs, S. Y. (2000). Wnt/beta-catenin signaling induces the expression and activity of betaTrCP ubiquitin ligase receptor. Molecular Cell, 5(5), 877-882.

Staal, F. J., Meeldijk, J., Moerer, P., Jay, P., van de Weerdt, B. C., Vainio, S., ... Clevers, H. (2001). Wnt signaling is required for thymocyte development and activates Tcf-1 mediated transcription. European Journal of Immunology, 31(1), $285-293$. ht tps://doi.org/ 10.1002/1521-4141(200101)31:1<285::AIDIMMU285>3.0.CO;2-D

Stark, G. R., and Darnell, J. E. (2012). The JAKSTAT pathway at twenty. Immunity, 36(4), 503-514. https://doi.org/10.1016/j.immuni. 2012.03.013

Stasik, C. J., Nitta, H., Zhang, W., Mosher, C. H., Cook, J. R., Tubbs, R. R., ... Rimsza, L. M. (2010). Increased MYC gene copy number correlates with increased mRNA levels in diffuse large B-cell lymphoma. Haematologica, 95(4), 597-603. https://doi.org/10.3324/haematol. 2009.012864

Staudt, L. M. (2010). Oncogenic activation of NFkappaB. Cold Spring Harbor Perspectives in Biology, 2(6), a000109. https://doi.org/10.1101/ cshperspect.a000109

Sumithra, B., Saxena, U., and Das, A. B. (2016). Alternative splicing within the Wnt signaling pathway: role in cancer development. Cellular Oncology (Dordrecht), 39(1), 1-13. https://doi.org/ 10.1007/s13402-015-0266-0

Tak, P. P., and Firestein, G. S. (2001). NF-kappaB: a key role in inflammatory diseases. The Journal of Clinical Investigation, 107(1), 7-11. https://doi.org/ $10.1172 / \mathrm{JCl} 11830$

Takada, I., Kouzmenko, A. P., and Kato, S. (2009). Wnt and PPARgamma signaling in osteoblastogenesis and adipogenesis. Nature Reviews. Rheumatology, 5(8), 442-447. https:// doi.org/10.1038/nrrheum.2009.137

Tan, J. T. M., McLennan, S. V., Song, W. W., Lo, L. W.-Y., Bonner, J. G., Williams, P. F., and Twigg, S. M. (2008). Connective tissue growth factor inhibits adipocyte differentiation. American Journal of Physiology. Cell Physiology, 295(3), C740-751. https://doi.org/10.1152/ajpcell.00333.2007

Tang, Q.-Q., Grønborg, M., Huang, H., Kim, J.-W., Otto, T. C., Pandey, A., and Lane, M. D. (2005). Sequential phosphorylation of CCAAT enhancerbinding protein beta by MAPK and glycogen synthase kinase 3 beta is required for adipogenesis. Proceedings of the National Academy of Sciences of the United States of America, 102(28), 9766-9771. https://doi.org/ 10.1073/pnas.0503891102 
Thompson, C. B. (2014). Wnt meets Warburg: another piece in the puzzle? The EMBO Journal, 33(13), 1420-1422. https://doi.org/10.15252/embj. 201488785

Tracey, L., Pérez-Rosado, A., Artiga, M. J., Camacho, F. I., Rodríguez, A., Martínez, N., ... Piris, M. A. (2005). Expression of the NF-kappaB targets BCL2 and BIRC5/Survivin characterizes small B-cell and aggressive B-cell lymphomas, respectively. The Journal of Pathology, 206(2), 123-134. https://doi.org/10.1002/path.1768

Valera, A., López-Guillermo, A., Cardesa-Salzmann, T., Climent, F., González-Barca, E., Mercadal, S., ... Grup per l'Estudi dels Limfomes de Catalunya i Balears (GELCAB). (2013). MYC protein expression and genetic alterations have prognostic impact in patients with diffuse large Bcell lymphoma treated with immunochemotherapy. Haematologica, 98(10), 1554-1562. https:// doi.org/10.3324/haematol.2013.086173

Vallabhapurapu, S., and Karin, M. (2009). Regulation and function of NF-kappaB transcription factors in the immune system. Annual Review of Immunology, 27, 693-733. https://doi.org/10.1146/annurev.immunol. 021908.132641

Vallée, A., and Lecarpentier, Y. (2016). Alzheimer Disease: Crosstalk between the Canonical Wnt/ Beta-Catenin Pathway and PPARs Alpha and Gamma. Frontiers in Neuroscience, 10, 459. https://doi.org/10.3389/fnins.2016.00459

Vallée, A., Lecarpentier, Y., Guillevin, R., and Vallée, J.-N. (2017a). Effects of Cannabidiol interactions with Wnt/B-catenin pathway and PPARy on oxidative stress and neuroinflammation in Alzheimer's disease. Acta Biochimica et Biophysica Sinica, 1-14. https://doi.org/10.1093/ abbs/gmx073

Vallée, A., Lecarpentier, Y., Guillevin, R., and Vallée, J.-N. (2017b). Thermodynamics in Gliomas: Interactions between the Canonical WNT/BetaCatenin Pathway and PPAR Gamma. Frontiers in Physiology, 8, 352. https://doi.org/10.3389/fphys. 2017.00352

van Amerongen, R., and Nusse, R. (2009). Towards an integrated view of Wnt signaling in development. Development (Cambridge, England), 136(19), 3205-3214. https://doi.org/ 10.1242/dev.033910

van Keimpema, M., Grüneberg, L. J., Mokry, M., van Boxtel, R., Koster, J., Coffer, P. J., ... Spaargaren, M. (2014). FOXP1 directly represses transcription of proapoptotic genes and cooperates with NF-KB to promote survival of human B cells. Blood,
124(23), 3431-3440. https://doi.org/10.1182/ blood-2014-01-553412

Villano, J. L., Koshy, M., Shaikh, H., Dolecek, T. A., and McCarthy, B. J. (2011). Age, gender, and racial differences in incidence and survival in primary CNS lymphoma. British Journal of Cancer, 105(9), 1414-1418. https://doi.org/ 10.1038/bjc. 2011.357

Vogt, P. K., and Hart, J. R. (2011). PI3K and STAT3: a new alliance. Cancer Discovery, 1(6), 481-486. https://doi.org/10.1158/2159-8290.CD-11-0218

Voskas, D., Ling, L. S., and Woodgett, J. R. (2010). Does GSK-3 provide a shortcut for PI3K activation of Wnt signalling? F1000 Biology Reports, 2, 82. https://doi.org/10.3410/B2-82

Walker, M. P., Stopford, C. M., Cederlund, M., Fang, F., Jahn, C., Rabinowitz, A. D., ... Major, M. B. (2015). FOXP1 potentiates Wnt/ $\beta$-catenin signaling in diffuse large $B$ cell lymphoma. Science Signaling, 8(362), ra12. https://doi.org/ 10.1126/scisignal.2005654

Wang, X.-H., Meng, X.-W., Xing, H., Qu, B., Han, M.-Z., Chen, J., ... Lu, Z.-W. (2011). STAT3 and beta-catenin signaling pathway may affect GSK-3beta expression in hepatocellular carcinoma. Hepato-Gastroenterology, 58(106), 487-491.

Warburg, O. (1956). On the origin of cancer cells. Science (New York, N.Y.), 123(3191), 309-314.

Wei, J., Bhattacharyya, S., Tourtellotte, W. G., and Varga, J. (2011). Fibrosis in systemic sclerosis: emerging concepts and implications for targeted therapy. Autoimmunity Reviews, 10(5), 267-275. https://doi.org/10.1016/j.autrev.2010.09.015

Wen, Z., Zhong, Z., and Darnell, J. E. (1995). Maximal activation of transcription by Stat1 and Stat3 requires both tyrosine and serine phosphorylation. Cell, 82(2), 241-250.

Whyte, W. A., Orlando, D. A., Hnisz, D., Abraham, B. J., Lin, C. Y., Kagey, M. H., ... Young, R. A. (2013). Master transcription factors and mediator establish super-enhancers at key cell identity genes. Cell, 153(2), 307-319. https://doi.org/ 10.1016/j.cell.2013.03.035

Wierstra, I., and Alves, J. (2008). The c-myc promoter: still MysterY and challenge. Advances in Cancer Research, 99, 113-333. https://doi.org/ 10.1016/S0065-230X(07)99004-1

Wu, J., Fang, J., Yang, Z., Chen, F., Liu, J., and Wang, Y. (2012). Wnt inhibitory factor-1 regulates glioblastoma cell cycle and proliferation. Journal of Clinical Neuroscience: Official Journal of the Neurosurgical Society of Australasia, 19(10), 1428-1432. https://doi.org/10.1016/j.jocn. 2011.12.023 
Wu, M., Arsura, M., Bellas, R. E., FitzGerald, M. J., Lee, H., Schauer, S. L., ... Sonenshein, G. E. (1996). Inhibition of c-myc expression induces apoptosis of WEHI 231 murine B cells. Molecular and Cellular Biology, 16(9), 5015-5025.

Xu, C., Wang, J., Zhu, T., Shen, Y., Tang, X., Fang, L., and Xu, Y. (2016). Cross-Talking Between PPAR and WNT Signaling and its Regulation in Mesenchymal Stem Cell Differentiation. Current Stem Cell Research and Therapy, 11(3), 247-254.

Yamasaki, S., Nakashima, T., Kawakami, A., Miyashita, T., Tanaka, F., Ida, H., ... Eguchi, K. (2004). Cytokines regulate fibroblast-like synovial cell differentiation to adipocyte-like cells. Rheumatology (Oxford, England), 43(4), 448-452. https://doi.org/10.1093/rheumatology/keh092

Yan, S., Zhou, C., Zhang, W., Zhang, G., Zhao, X., Yang, S., ... Xu, N. (2008). beta-Catenin/TCF pathway upregulates STAT3 expression in human esophageal squamous cell carcinoma. Cancer Letters, 271(1), 85-97. https://doi.org/10.1016/ j.canlet.2008.05.035

Yang, J., Liao, X., Agarwal, M. K., Barnes, L., Auron, P. E., and Stark, G. R. (2007). Unphosphorylated STAT3 accumulates in response to IL-6 and activates transcription by binding to NFkappaB. Genes and Development, 21(11), 1396-1408. https://doi.org/10.1101/gad.1553707

Yang, Z., Wang, Y., Fang, J., Chen, F., Liu, J., Wu, J., ... Rao, Y. (2010). Downregulation of WIF-1 by hypermethylation in astrocytomas. Acta Biochimica Et Biophysica Sinica, 42(6), 418-425.

Yokogami, K., Wakisaka, S., Avruch, J., and Reeves, S. A. (2000). Serine phosphorylation and maximal activation of STAT3 during CNTF signaling is mediated by the rapamycin target mTOR. Current Biology: $C B, 10(1), 47-50$.

$\mathrm{Yu}$, J. S. L., and Cui, W. (2016). Proliferation, survival and metabolism: the role of PI3K/AKT/ mTOR signalling in pluripotency and cell fate determination. Development (Cambridge, England), 143(17), 3050-3060. https://doi.org/ 10.1242/dev. 137075

Yue, X., Lan, F., Yang, W., Yang, Y., Han, L., Zhang, A., ... Kang, C. (2010). Interruption of $\beta$-catenin suppresses the EGFR pathway by blocking multiple oncogenic targets in human glioma cells. Brain Research, 1366, 27-37. https://doi.org/ 10.1016/j.brainres.2010.10.032

Yun, K., Choi, Y. D., Nam, J. H., Park, Z., and Im, S.-H. (2007). NF-kappaB regulates Lef1 gene expression in chondrocytes. Biochemical and Biophysical Research Communications, 357(3), 589-595. https://doi.org/10.1016/j.bbrc. 2007.03.170

Zhang, H. H., Huang, J., Düvel, K., Boback, B., Wu, S., Squillace, R. M., ... Manning, B. D. (2009). Insulin stimulates adipogenesis through the AktTSC2-mTORC1 pathway. PloS One, 4(7), e6189. https://doi.org/10.1371/journal.pone.0006189

Zhang, Yan, Wang, C.-P., Ding, X.-X., Wang, N., Ma, F., Jiang, J.-H., ... Chang, J.-B. (2014). FNC, a novel nucleoside analogue, blocks invasion of aggressive non-Hodgkin lymphoma cell lines via inhibition of the $\mathrm{Wnt} / \mathrm{\beta}$-catenin signaling pathway. Asian Pacific Journal of Cancer Prevention: APJCP, 15(16), 6829-6835.

Zhang, Yuhang, Tomann, P., Andl, T., Gallant, N. M., Huelsken, J., Jerchow, B., ... Schmidt-Ullrich, R. (2009). Reciprocal requirements for EDA/EDAR/ NF-kappaB and Wnt/beta-catenin signaling pathways in hair follicle induction. Developmental Cell, 17(1), 49-61. https://doi.org/10.1016/j.devcel. 2009.05.011

Zhou, K., Xu, D., Cao, Y., Wang, J., Yang, Y., and Huang, M. (2014). C-MYC aberrations as prognostic factors in diffuse large B-cell lymphoma: a meta-analysis of epidemiological studies. PloS One, 9(4), e95020. https://doi.org/ 10.1371/journal.pone.0095020 